\title{
سمات فن التجميع كمصدر لتصميم فانتازيا الأزياء
}

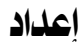 \\ م/ رباب حسر . محمد \\ أستاذ مساعد بقسم الملابس والنسيج \\ كلية الاقتصاد المنزلي جامعة حلوان
}

مجلة بحوث التربية النوعية ـ جامعة المنصورة

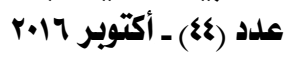


בب سمات فن التجميع كمصلر تتصميهر فانتازيا اצزياء 


\title{
سمات فن التجميع كمصدر لتصميم فانتازيا الأزياء
}

\author{
إعداد \\ د/رباب حسنمحمد
}

هـدف البحــث إلى : اسـتخلاص الأسـس والمعـايير التـى يعتهـــ علـى أسـاسـها بنـاء العهـل

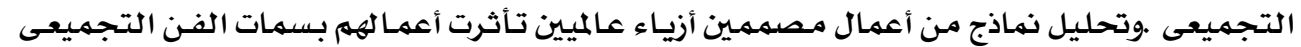

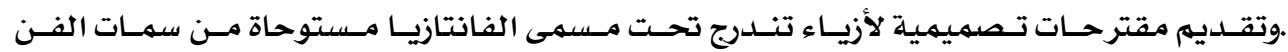

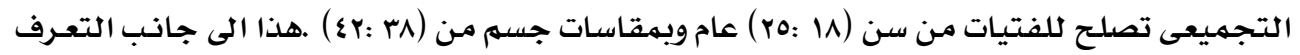

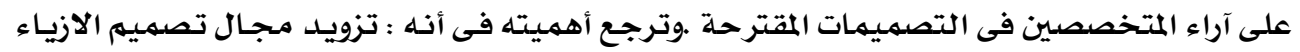

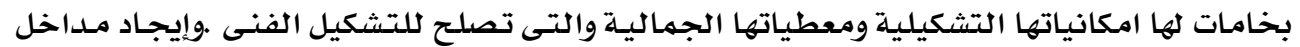

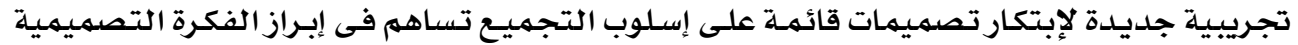

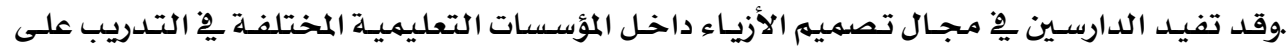

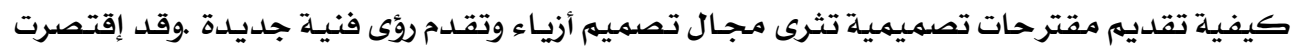

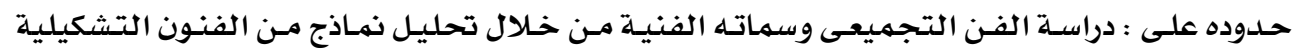

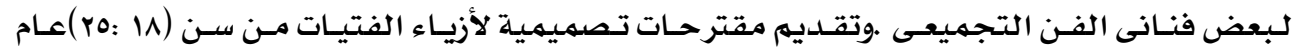

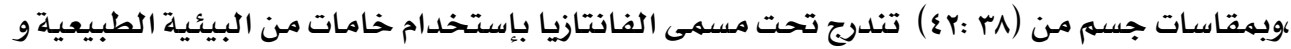

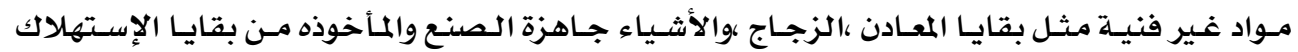

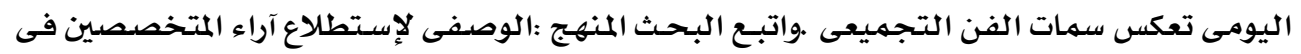
التصميمات المقترحسة .

\section{وقد أسفرت نتائجه عن :}

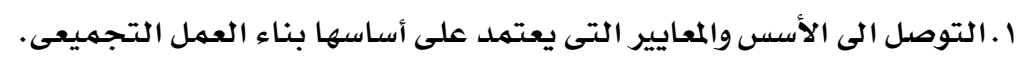

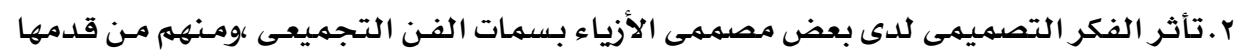

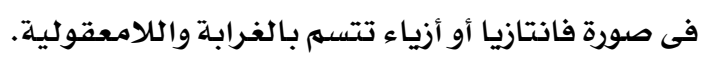

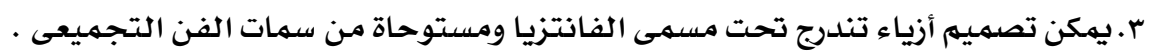

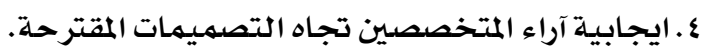

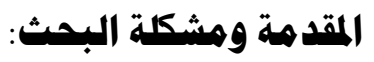

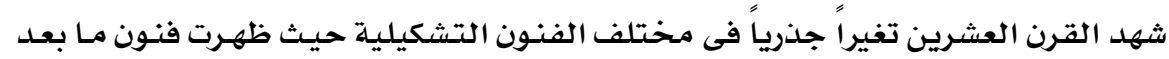

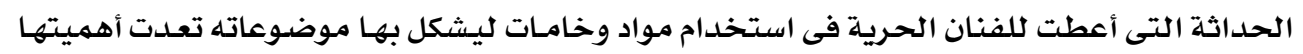

•أستاذ مساعد بقسم الملابس والنسيج- كلية الإقتصاد المنزلى جامعة حلوان 
من كونها وسيلة من وسائل التشكيل لتصبح هى الغاية أحيانا. مما أدى إلى إحداث نقلـة نوعيـة فنيـة

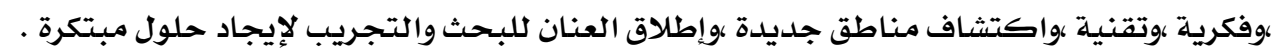

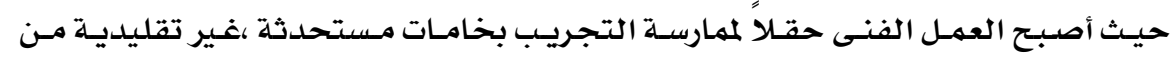

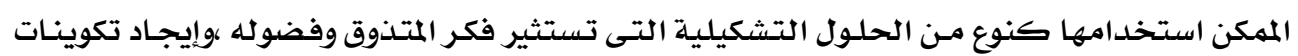

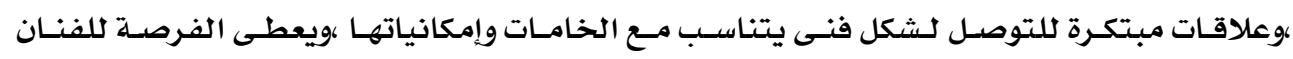

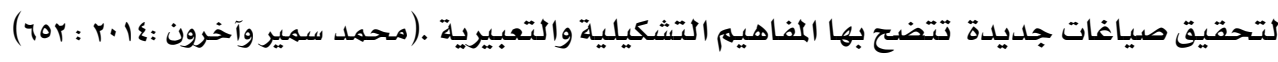
ولما أن فن تصميهم الأزياء يعد من الفنون التشكيلية التى تعايث الواقع ،وتعتمد على توليف

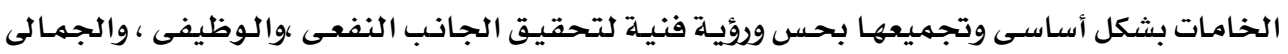

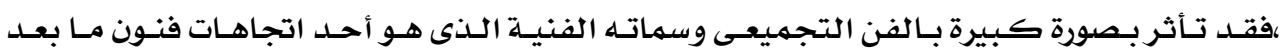

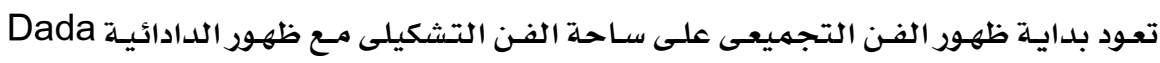

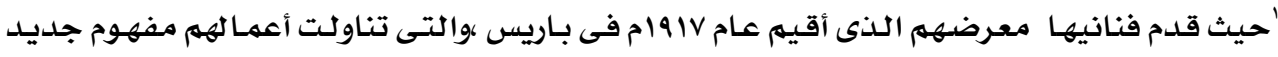

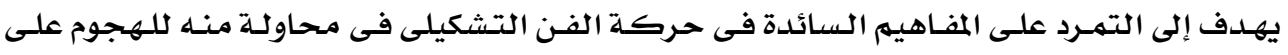

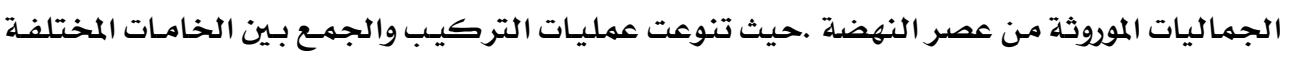

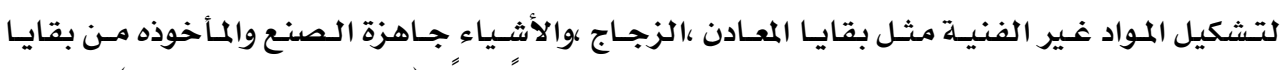

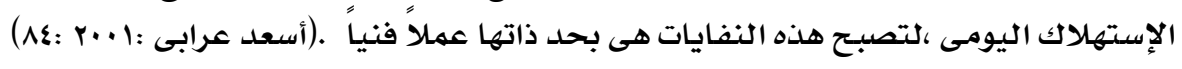

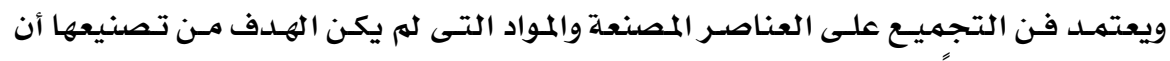

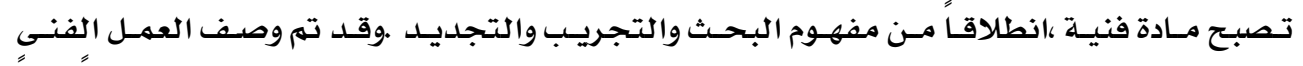

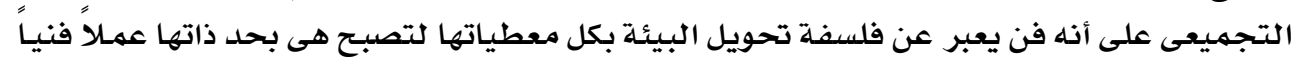

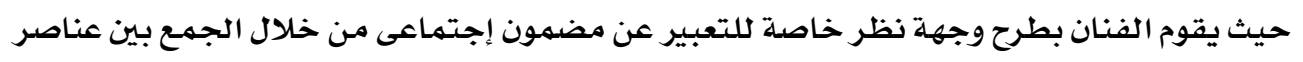

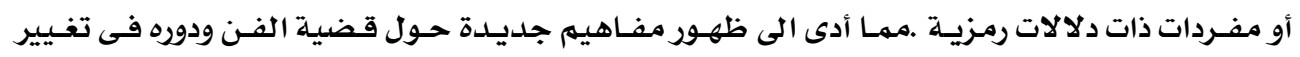

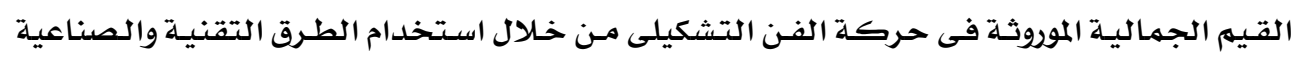

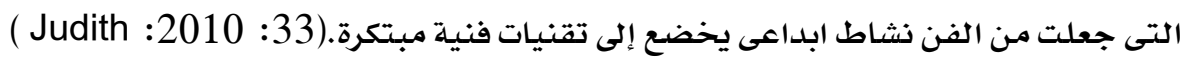

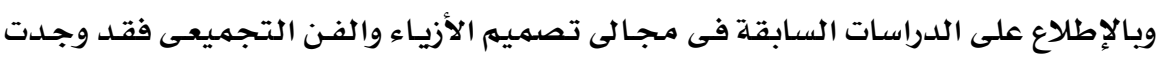

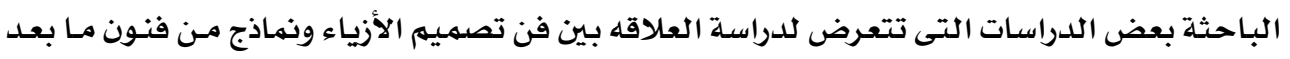

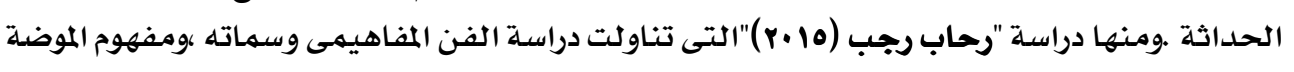

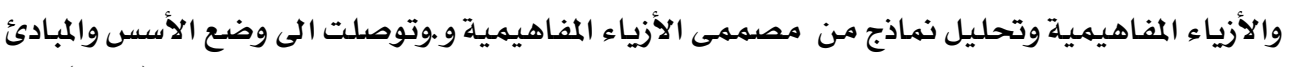

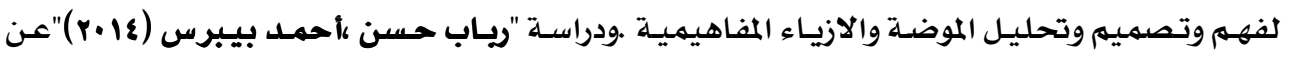

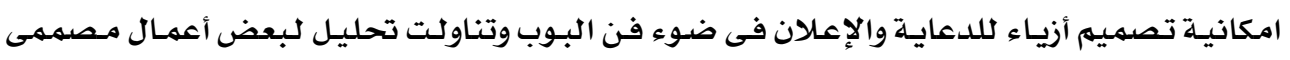

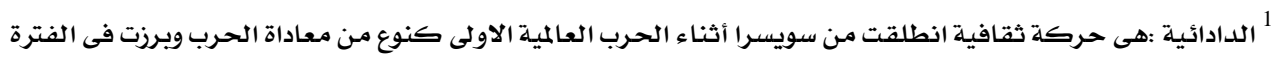

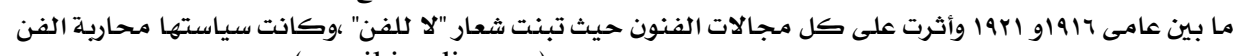
بالفن وتجاهلت علم الجمال وتخريب كل ابرل أشكال الفن التقليدى. (ar.wikipedia.org) 


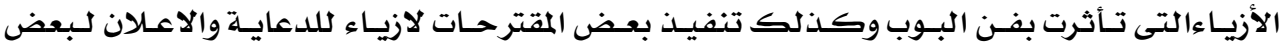

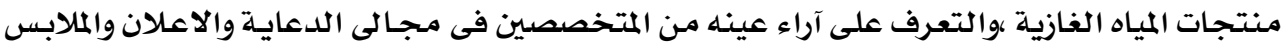

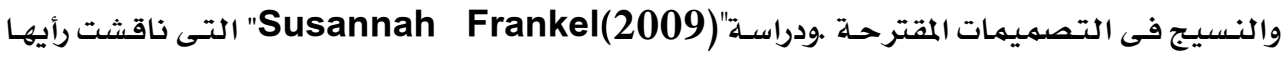

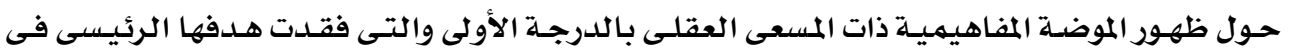

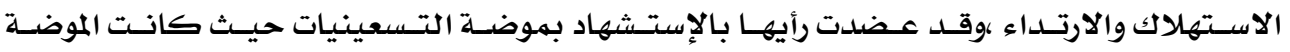

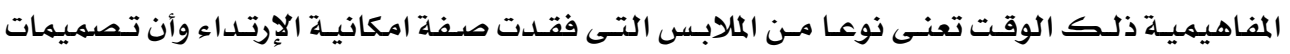

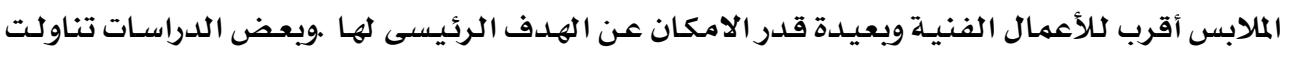

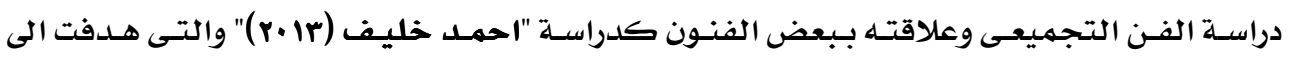

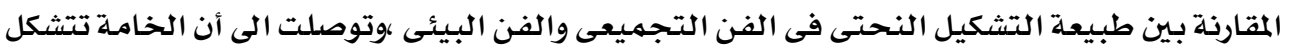

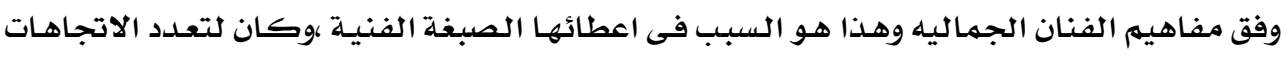

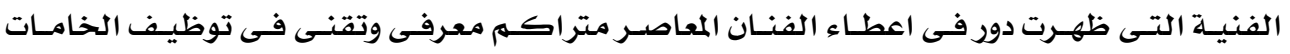

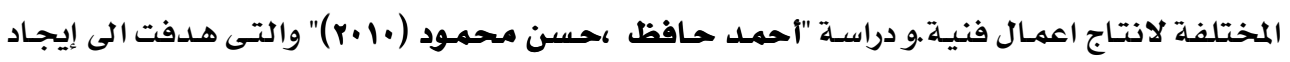

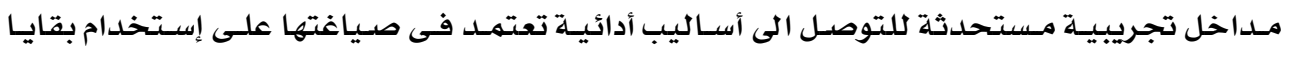

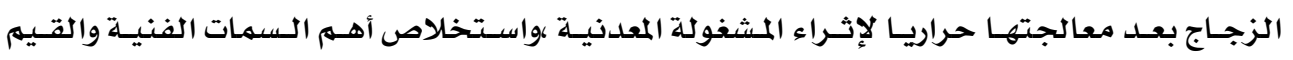

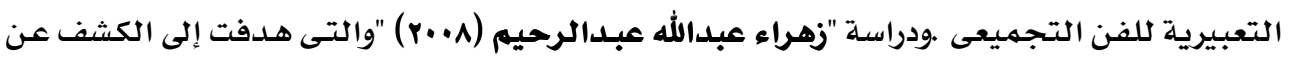

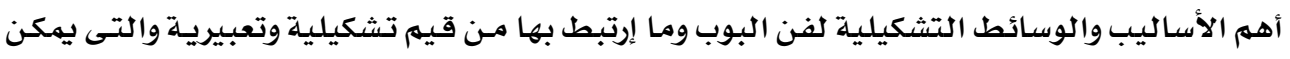

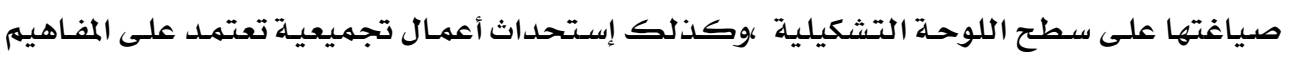

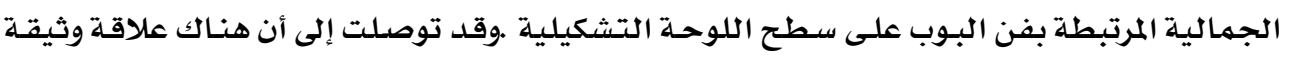

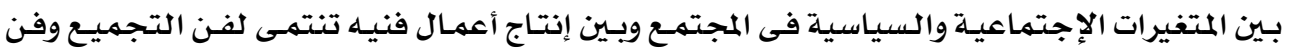

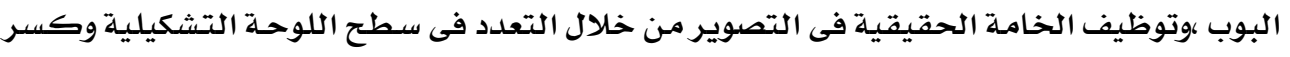

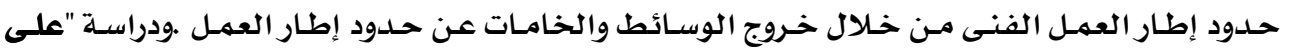

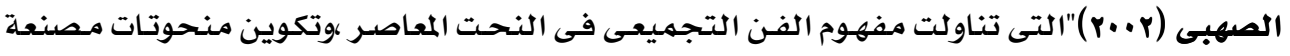

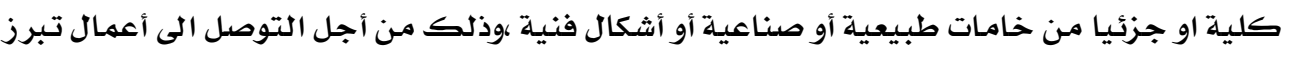

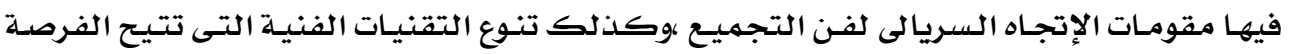

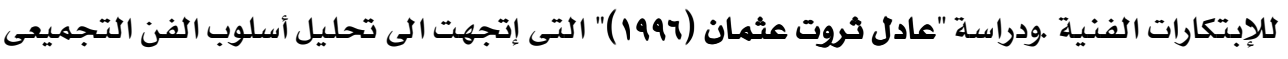

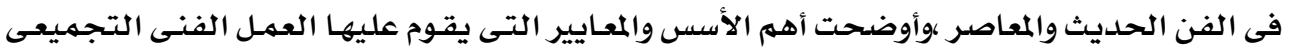

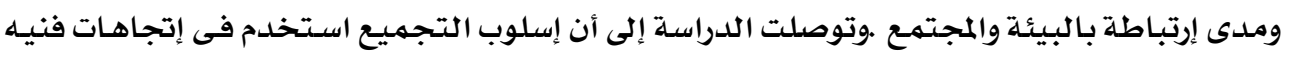

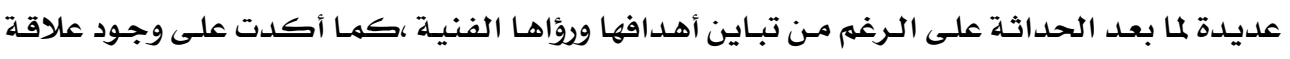

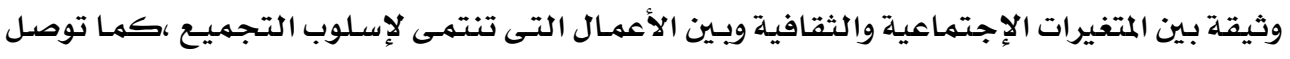

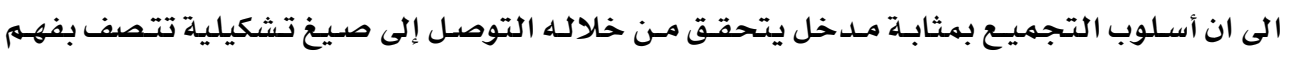
الخامة والوعى بإمكانياتها.

ومما سبق يتضـح ندرة الدراسات العربية التى تتناولت العلاقة بين فن تصميه الأزياء وفنـون

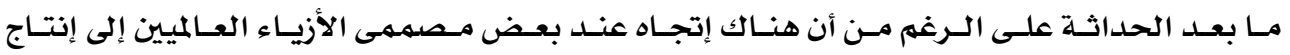


تصميمات تعكس فكر وسمـات وفلسفة فنون مـا بعـد الحداثلة .وذلك مهما دعى الباحثه لتنـاول الفن

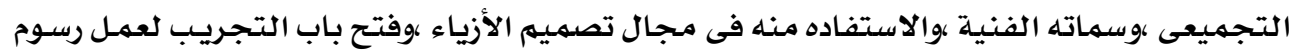

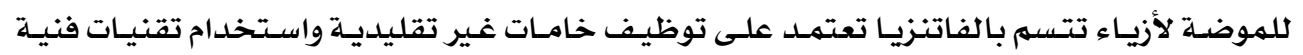

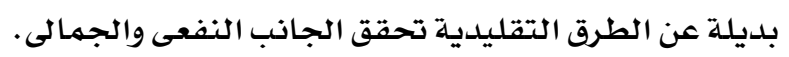

\section{وبالتالي يمكن صياغة مشكلة البحث فى التساؤلات التالية:}

$$
\text { ا ب. ما المقصود بالفن التجميعى وأسباب ظهوره؟ }
$$

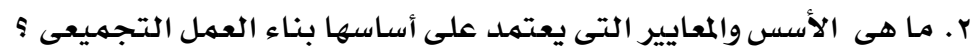

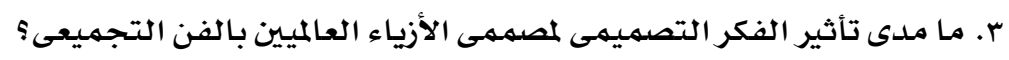

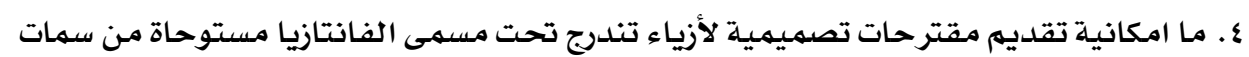

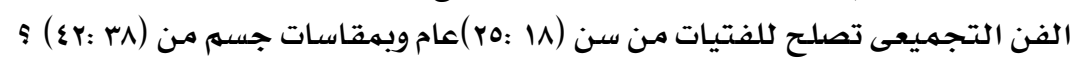

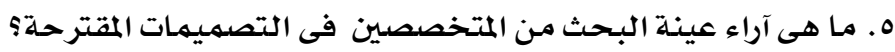

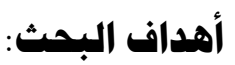

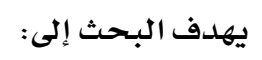

ا ـ استخلاص الأسس والمعايير التى يعتمد على أساسها بناء العمل التجميعى.

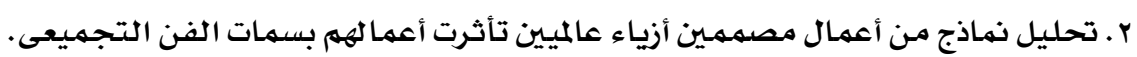

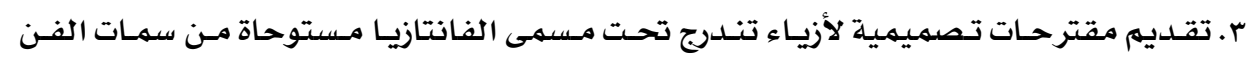

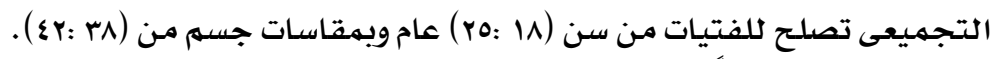

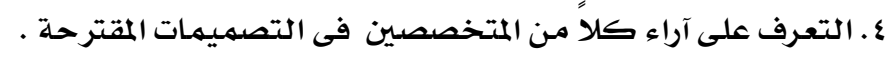

$$
\text { ترجـع أهمية البحث إلى : }
$$

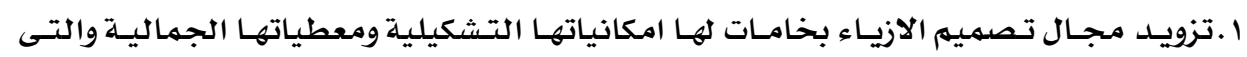

$$
\text { تصلح للتشكيل الفنى. }
$$

ץ. ايجاد مداخل تجريبية جديدة لإبتكـار تصميمات قائمـة على إسـلوب التجميـع تسـاهم فى إبراز

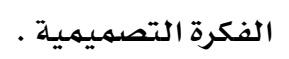

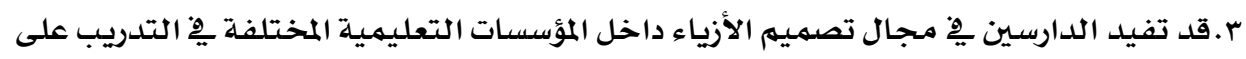

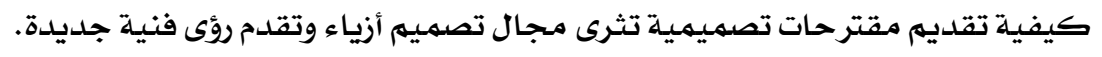

\section{هدود البمث:}

$$
\text { يقتصر البحث الحالي على: }
$$

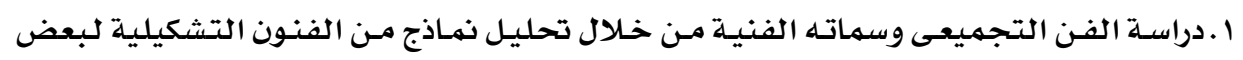

فنانى الفن التجميعى. 


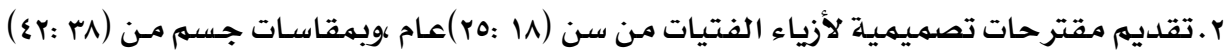

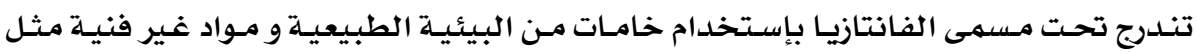

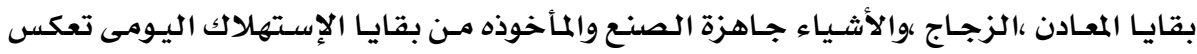
سمات الفن التجميعى.

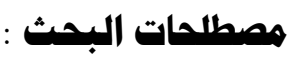

\section{فن التجميع : Assemblage art}

- هو اسلوب فنى يعتمد على التجميـع والتراكيب للخامـات المختلفـة (الطبيعيـة أو الصناعية)

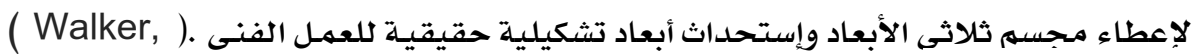
John : 1992: 78

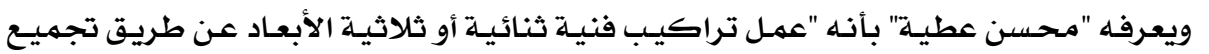

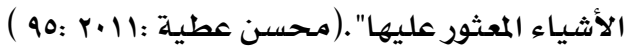

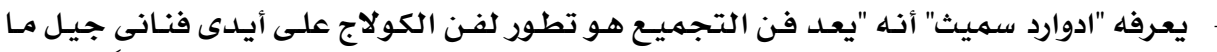

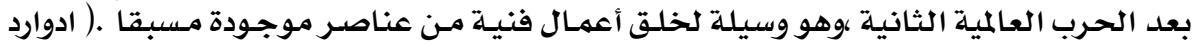

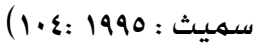

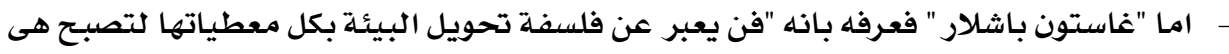

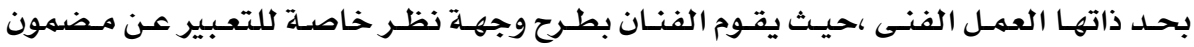

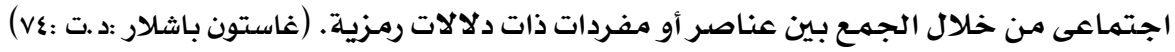
Phantasy - Fantasy : الفالتزيا

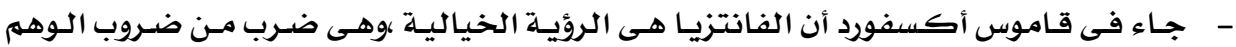

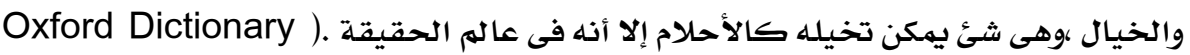
(:1999:341

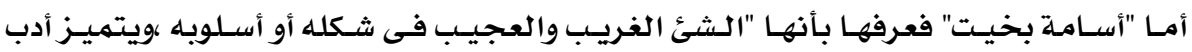

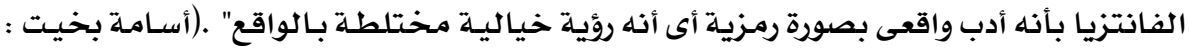
(1\&r: r... وتعرف "رحاب رجب" الفانتزيا فى تصميم الأزيـاء بأنها "هى أزيـاء تبـدو بشكل غريبب وأحيانا

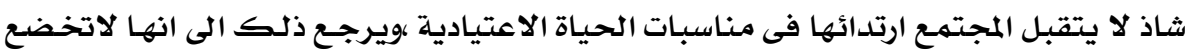

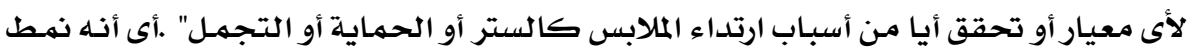

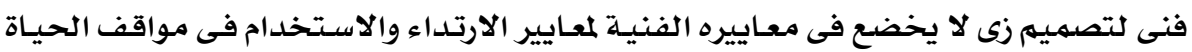

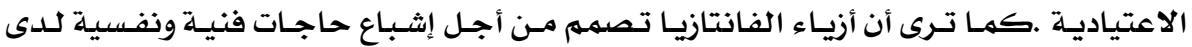

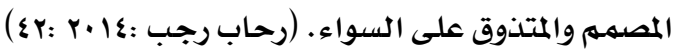


- وتعرفه الباحثة اجرائياً أنه تصميم أزياء غريبة ثلاثية الأبعاد تعتمد على تجميـع خـامـات غير

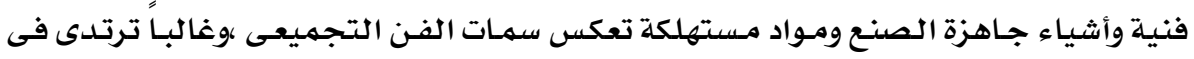

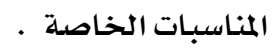

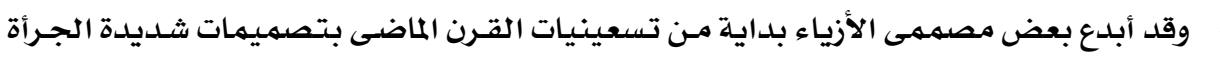

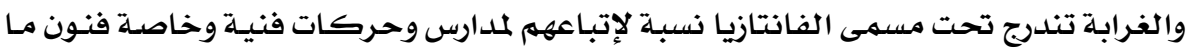

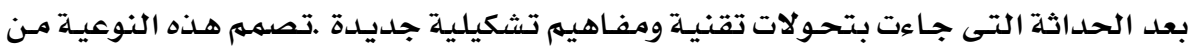

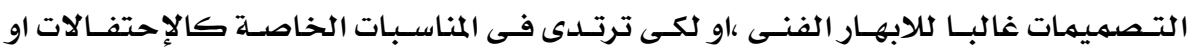

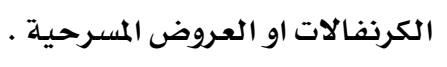

تصميي الأزياء"Fashion Design":

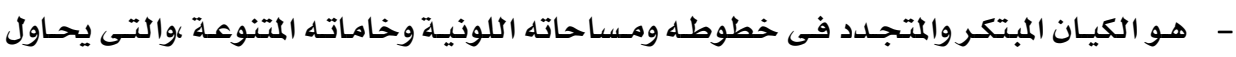

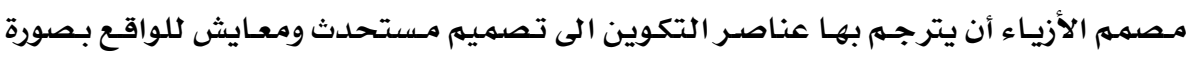

تشكيلية. (William Benton:1996:298)

\section{هنهج البحث وإجراءاته:}

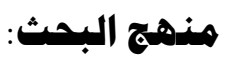

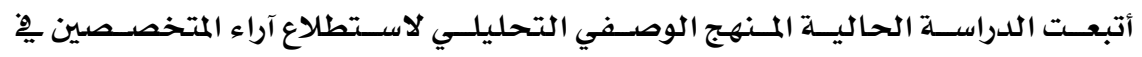

التصميمات المقترحة.

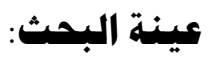

تكونت عينة البحث من:

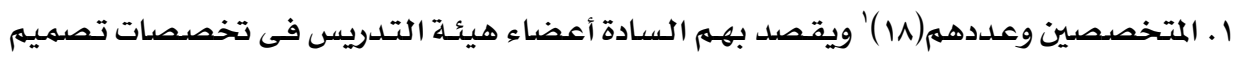

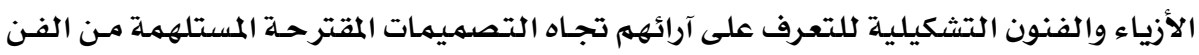

$$
\text { التجميعى. الأباء. }
$$

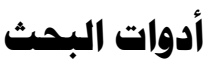

• استبيان أراء المتخصصين : ملحق رقم (1)

الهدف من الاستبانة: التعرف على آراء المتخصصين فى تصميمات فانتزيا الأزياء المستوحاة

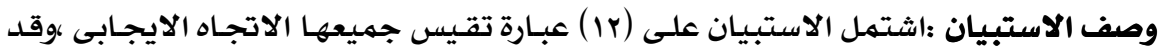

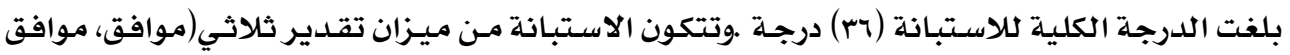

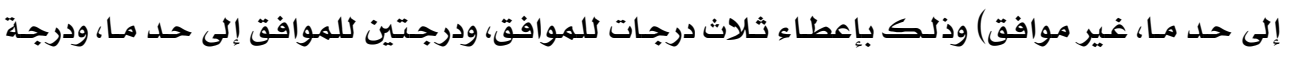

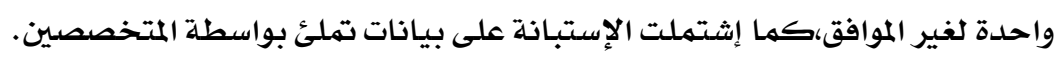

' أسماء السادة المتخصصين ووظائفهـم ملحق رقم (r) 


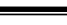

صدق الاستبيان :للتحقق من صدق الاستبيان تم عرض الصورة المبدئية لها على مجموعة

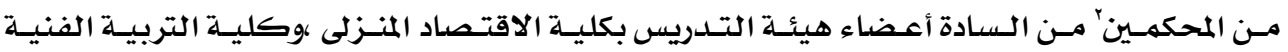

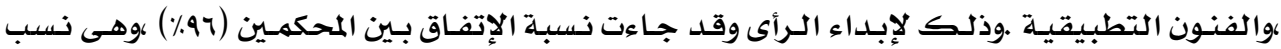

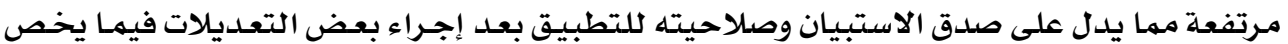
ترتيب وصياغة بعض العبارات .

ثبات الاستبيان :تم حساب الثبات عن طريق ( معامل الفا كرونباك) حيث بلغ معامل ثبات

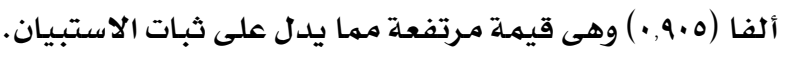

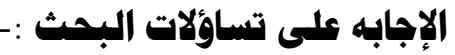

\section{• التساؤل الاول : ما المقصود بالثن التجميعى وأسباب ظهوره؟}

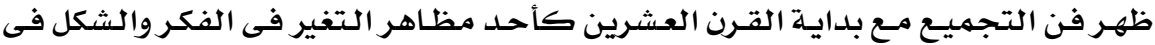

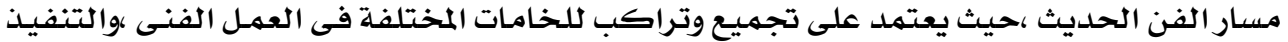

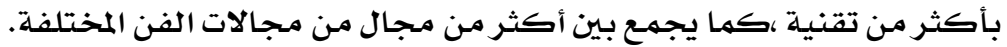

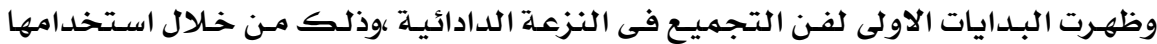

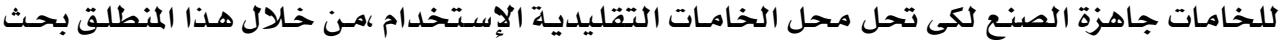

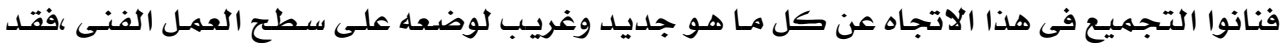

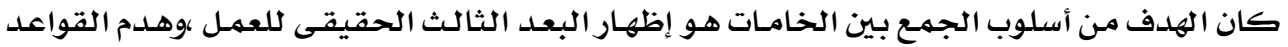

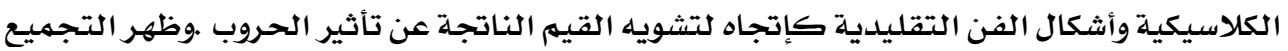

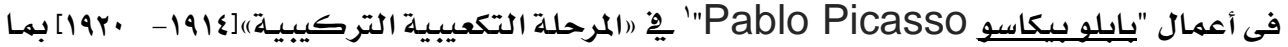

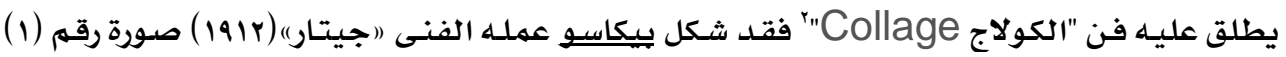

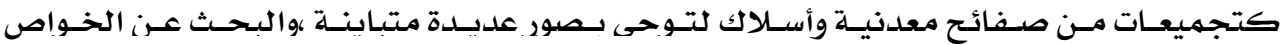

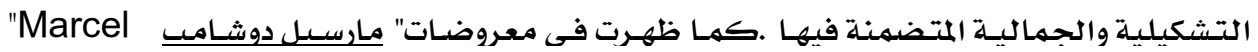

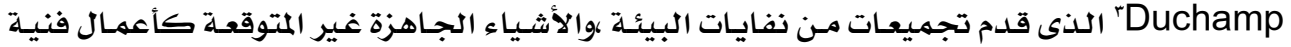

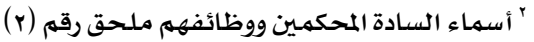
بابلو بيكاسو (1MM1:

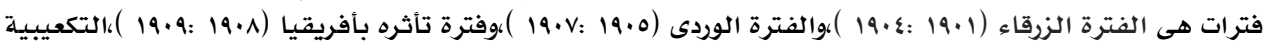

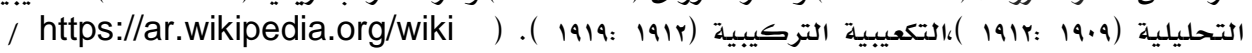

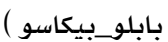

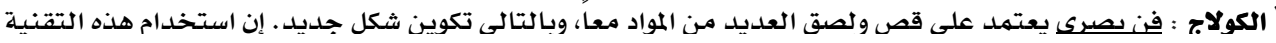

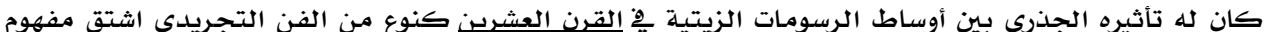
الكولاج من اللفظ Collar والذى اخترعه Georges Braque وبيكاسي

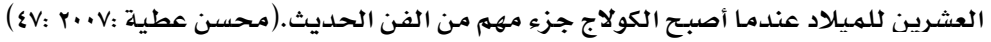

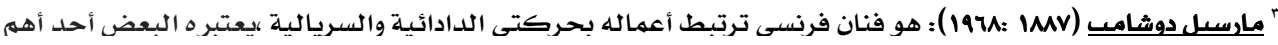

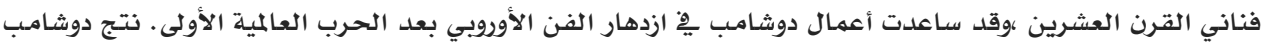




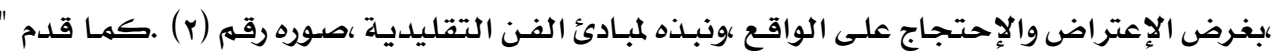

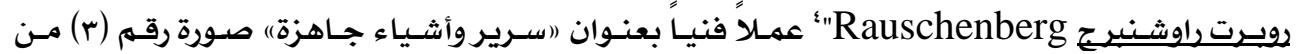

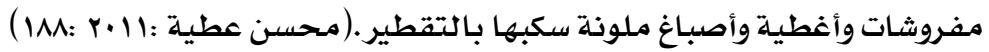

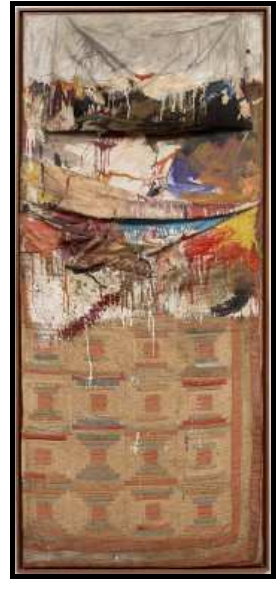

صورة رقم (r) (ماء)

"سرير وأشياء جاهزة" راوشنبرج عام 1900

المقاس r.r.r.

https://www.moma.org/lear n/moma_learning/robertrauschenberg-bed-1955

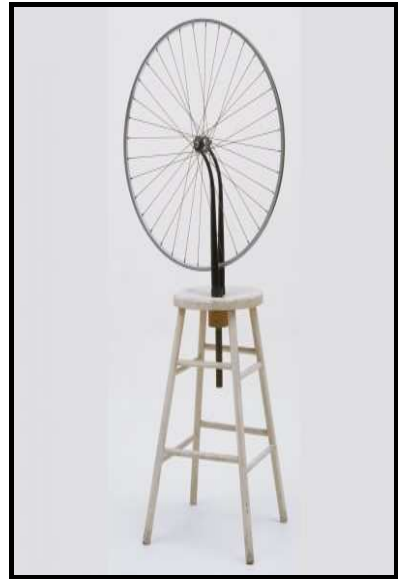

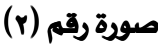

$$
\begin{aligned}
& \text { "عجلة على كرسى" } \\
& \text { خشب"مارسيل دوشامب" عام190 }
\end{aligned}
$$$$
\text { المقاس:0, }
$$
https://www.moma.org/lear $\mathrm{n} /$ moma_learning/marcelduchamp-bic

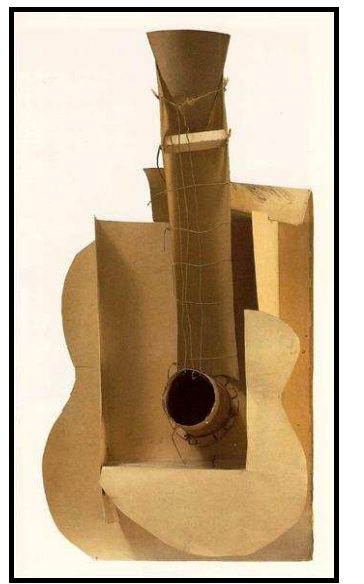

\section{صورة رقم (1)}

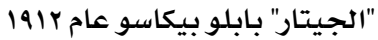

المقاس:VV,OX ro

متحف الفن الحديث - نيويورك http://www.wikiart.org/en/p ablo-picasso/guitar-1912

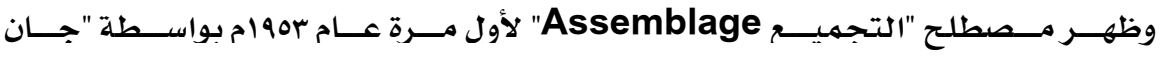

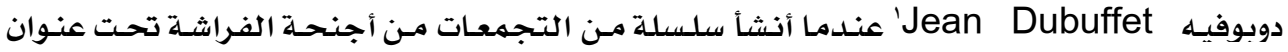

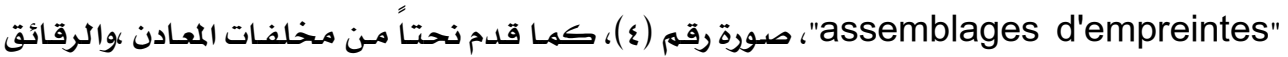

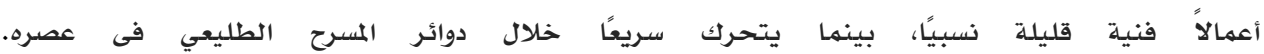

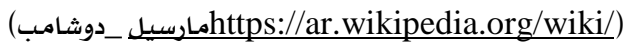

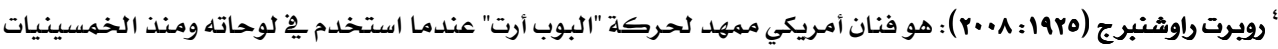

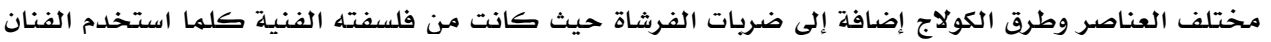

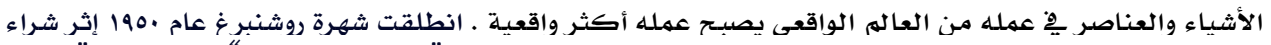

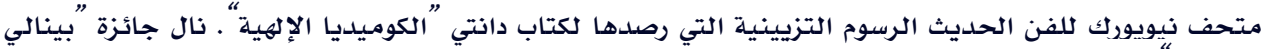

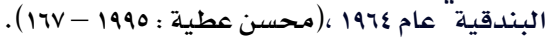

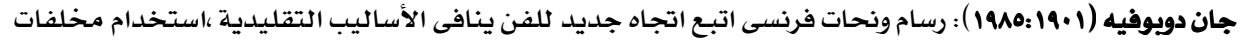

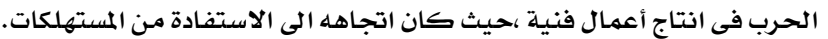
https://en.wikipedia.org/wiki/Jean_Dubuffet 


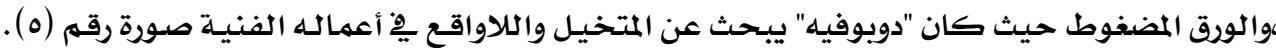

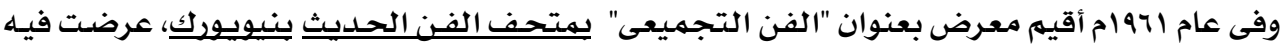

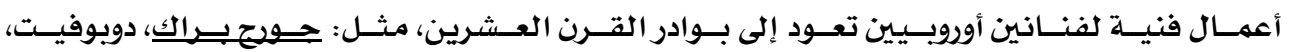

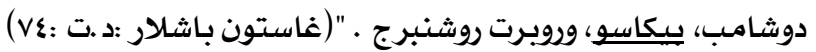

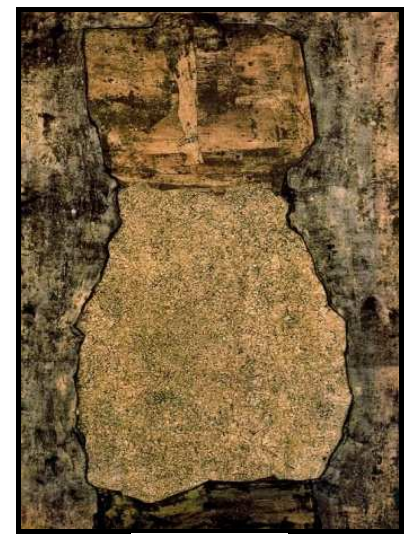

صورة رقم (0)

"الطائر فى الضوء" للفنان جان دوبوفيه عام

1909

V£XII7: المقاس

http://instareyog.blogspot.com.eg

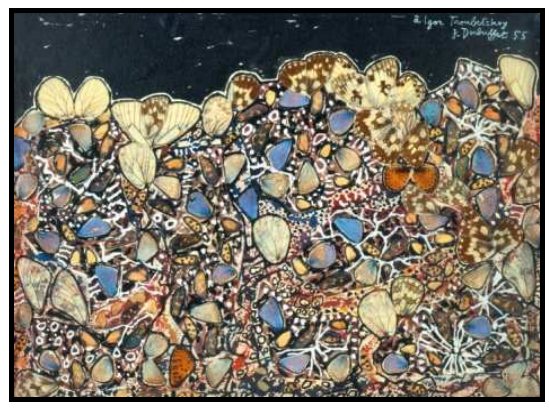

صورة رقم (ع)

"assemblages d'empreintes"

$$
\text { دوبوفيه عام 1900م }
$$

http://www.artnews.comconvincedart -jean-dubuffet-paints-a-picture

\section{من أعلام الفز التجميعى :}

فلاديهـير تـاتلـين مصنوعة من الخشب والحديد معلقة على زوايا الحائط منذ عشرات القرن الماضى.

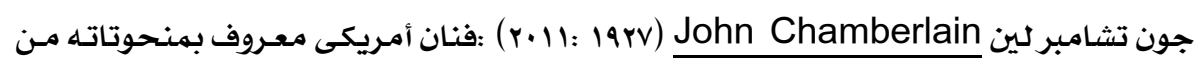
القطع الملحومة من حطام السيارات .

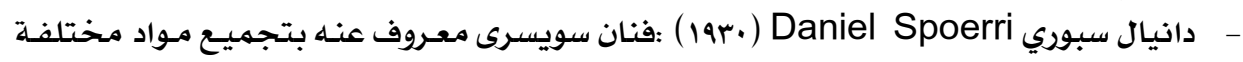

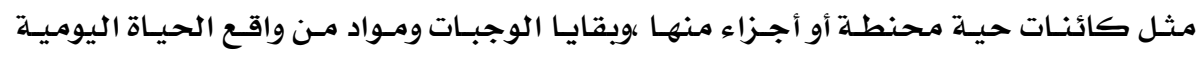
وتثبيتها على لوح فنية لعمل بناء تشكيلى.

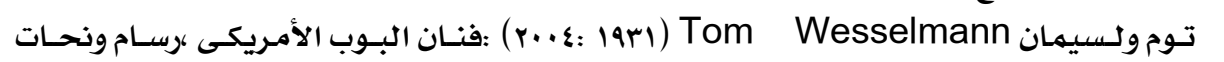

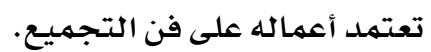

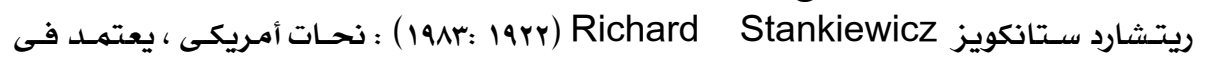
( https://en.wikipedia.org/wiki/Assemblage_(art) 


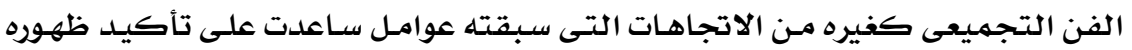

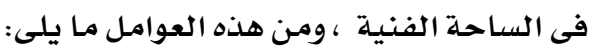

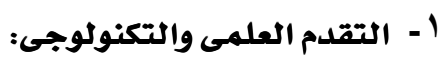

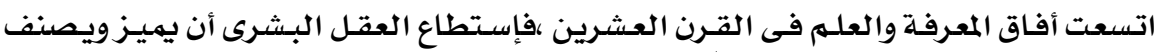

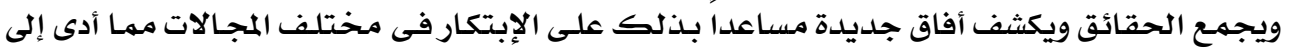

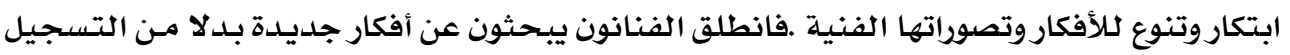

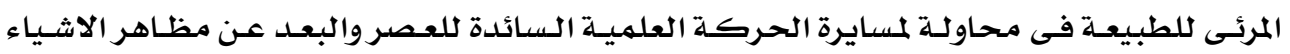

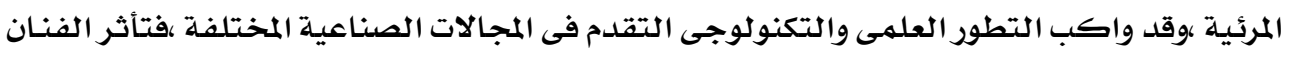

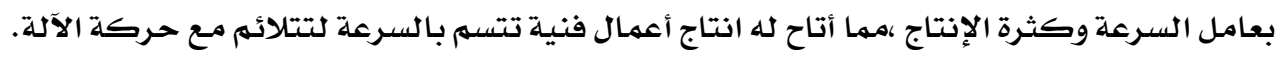

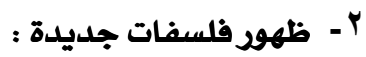
أ- فلسفة هنرى بيرجسون:

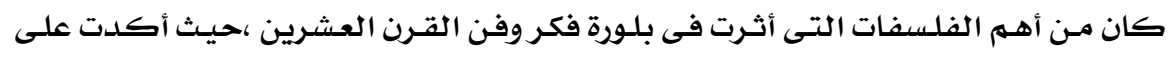

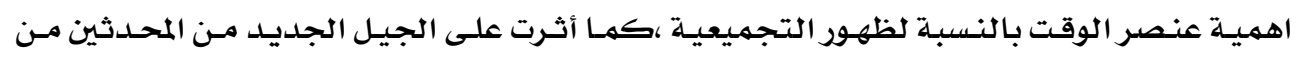

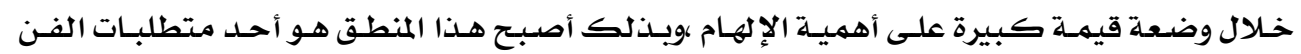
التشكيلى.

\section{ب- منهج الظواهر "هيدجر:}

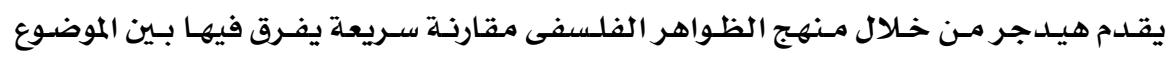

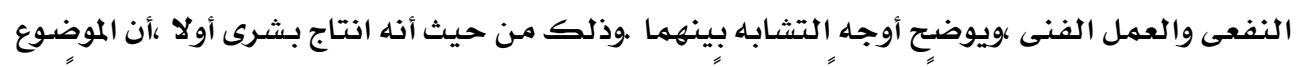

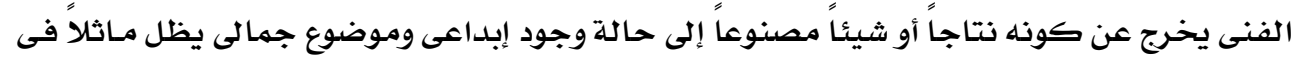
العمل الفنى ذاته.

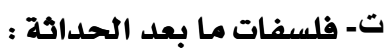

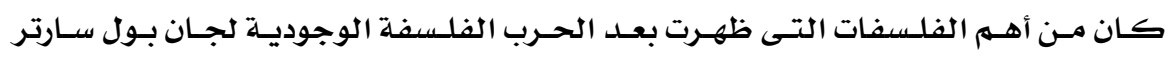

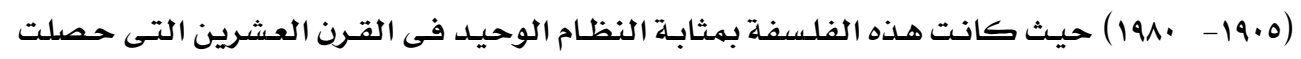

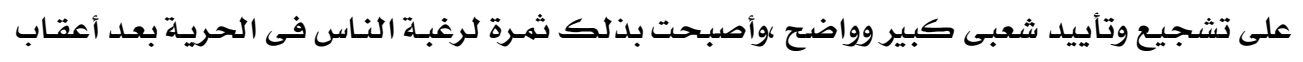

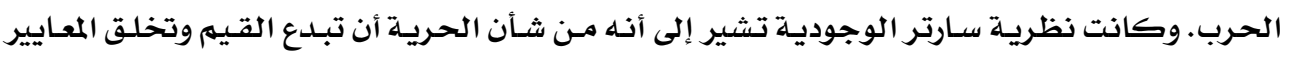

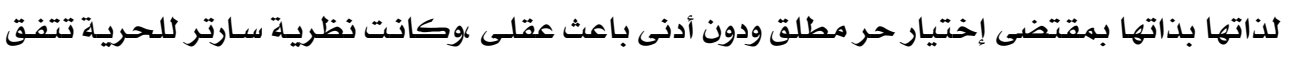

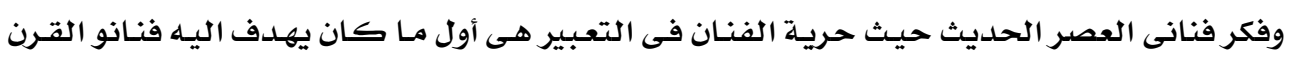

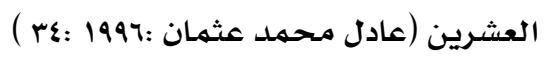

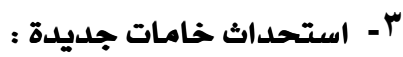

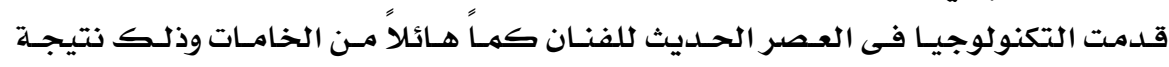

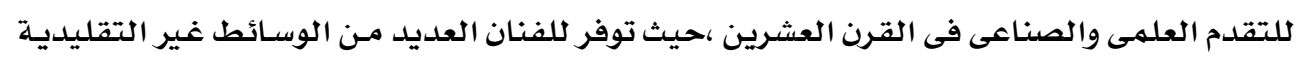

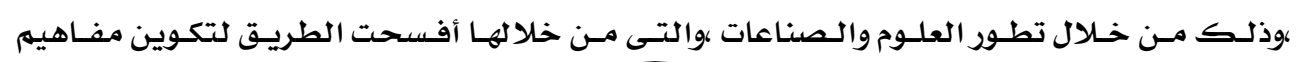


تشكيلية جديـدة سـاعدت على تحسرر الفنـان التشكيلي مـن الحسدود التى فرضـتها المعـايير والخامـات

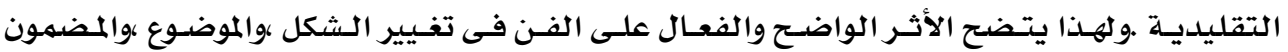
،وطريقة الإسلوب ،مما ساعد الفنان من تحقيق أفكاره.

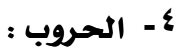

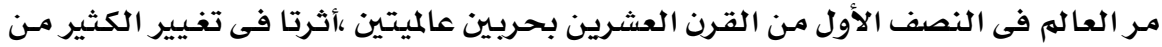

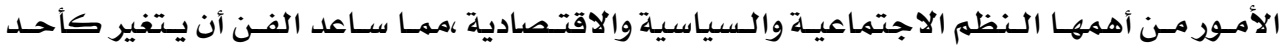

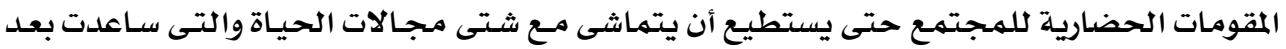

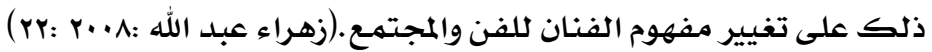
• التساؤل الثانى : ما هى الأسس والمعايير التى يعتمد على أساسها بناء العمل التجميعى ؟ يتم التوصل للسمات التشكيلية للفن التجميعى والأسس والمعايير التى يعتمد على أساسها

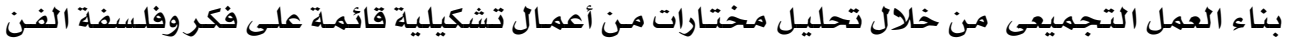

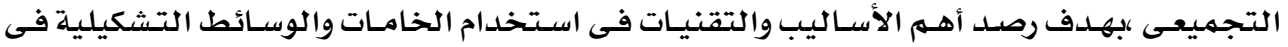
العمل الفنى. ويتمى التحليل من خلاليل : - الوصف العام للعمل الفنى والخامات والوسائط التشكيلية المستخدمـة.

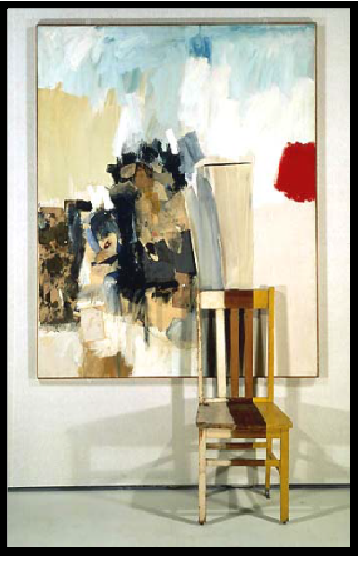

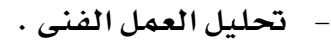

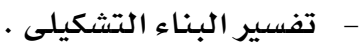
وصف العمل الفنى: Robert Rauschenberg اسهم الفنان : روبرت رشنبرغ Pilgrim : اسهم العمل : العمل 19X0\&XV9 : أبعاد العمل الخامات : خشب ،كرسى ،وسائط مختلفة .

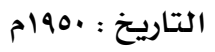

صورة رقم (7) (1) - (1)

تحليل العمل الفنـى:العمـل عبـارة عن مسـاحة مستطيلة الشكل يكسر إطـار حسدود العمـل

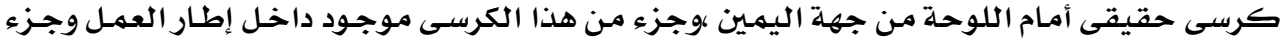
منـه خارج اطار العمل.

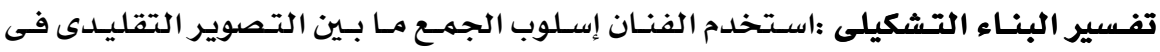

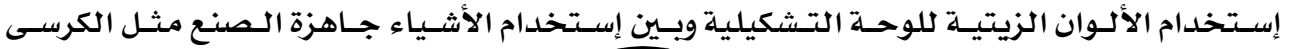




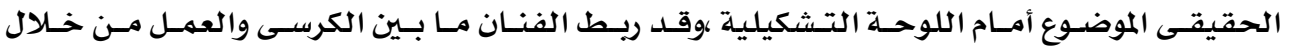

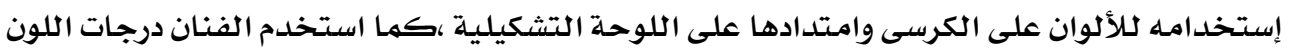

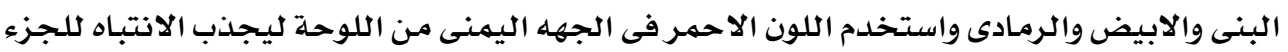
الأبيض.

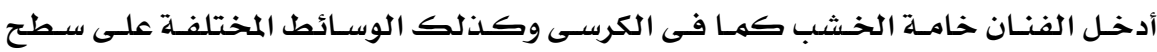

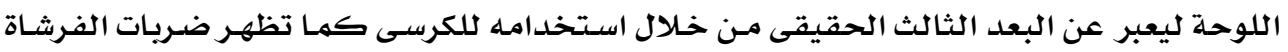

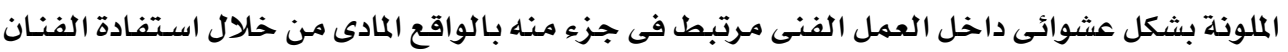

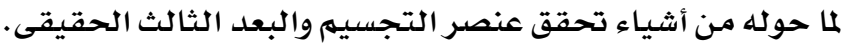

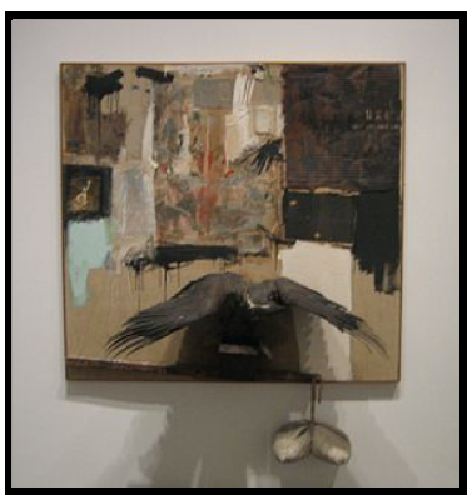

وصف العمل الفنى:

Robert Rauschenberg اسهم الفنان : روبرت رشنبرغ وهم:

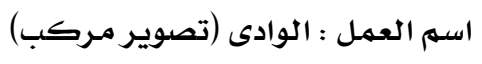

أبعاده

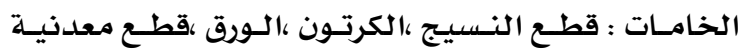

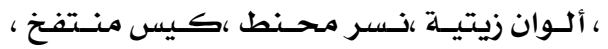

حبال.

التاريخ :

صورة رقم (v) (2) (2)

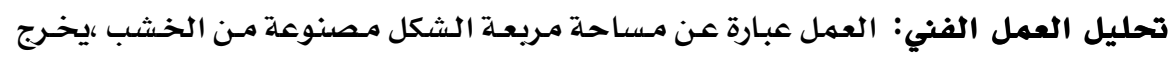

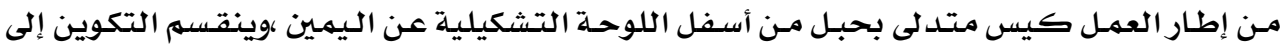

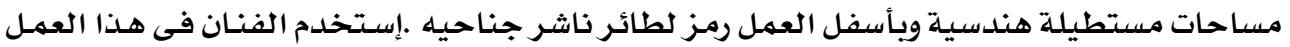

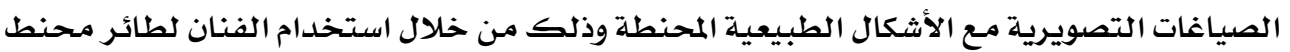

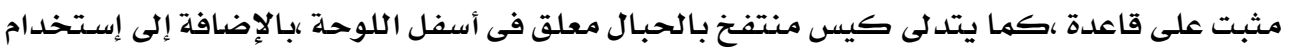

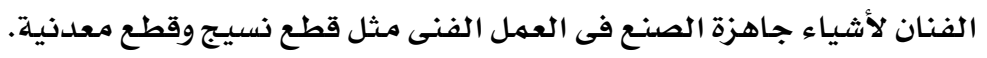

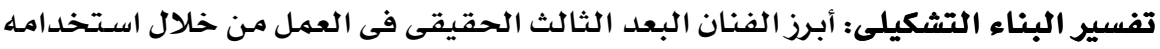

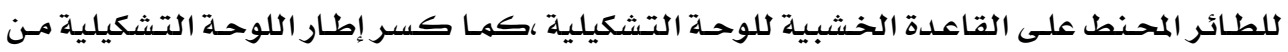

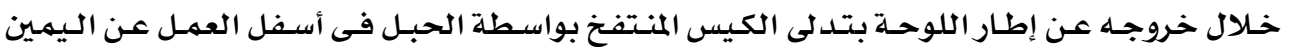

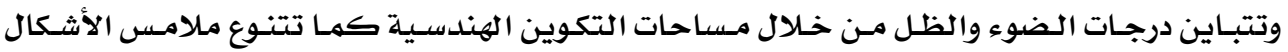




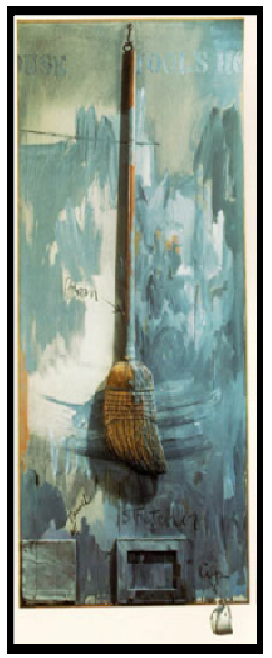

$$
\begin{aligned}
& \text { وصف العمل الفنى: } \\
& \text { اسهم الفنان : جاسبر جونز Jasper Johns } \\
& \text { اسهم العمل : بيت الأبله الهبه } \\
& \text { أبعاده : }
\end{aligned}
$$

الخامات :زيت على توال ،خامات جاهزة الصنع (مكنسلة بوهن

، قطع خشبية ،فنجان.

التاريخ :

صورة رقم (A)

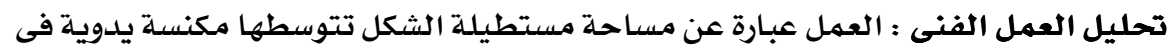

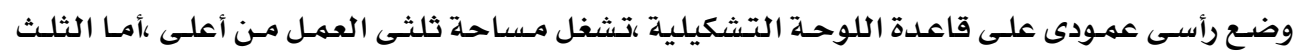

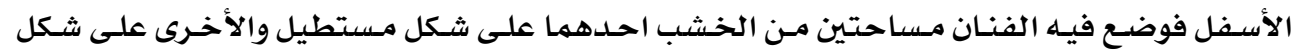

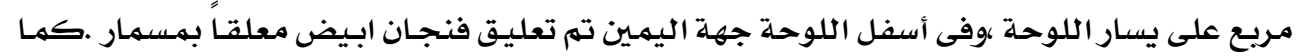

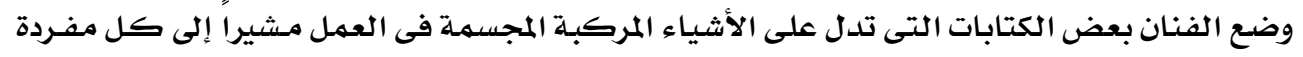

$$
\text { بسهم مرسوم. }
$$

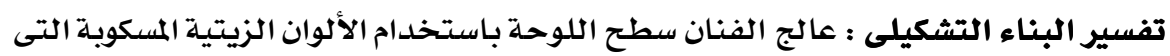

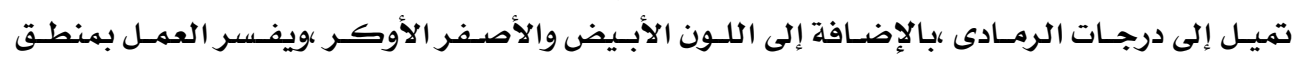

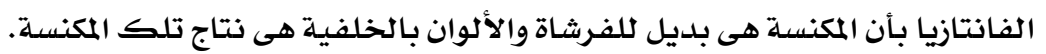

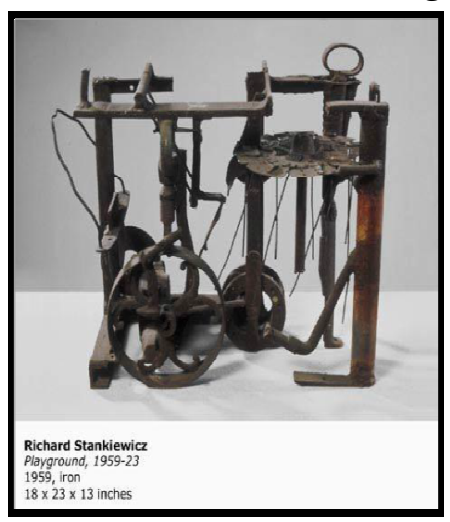

وصف العمل الفنى:

اسهم الفنان : ريتشارد ستانكويز اسفئ

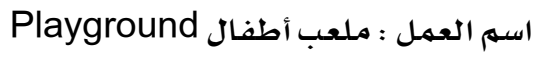

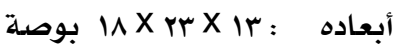
الخامات : حلديد : البعاده : التاريخ : الخامات : التوليل

(Judith :2010:36)

صورة رقم (q) 


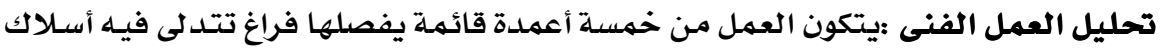

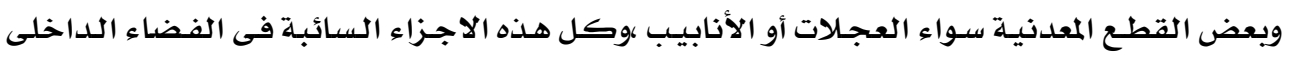

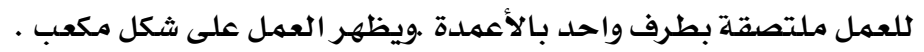

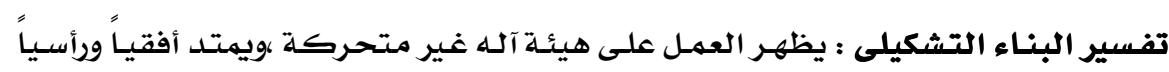

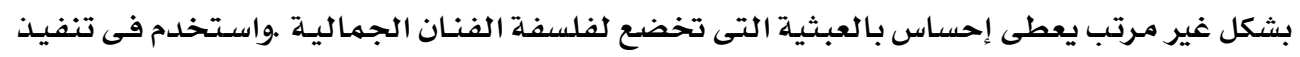

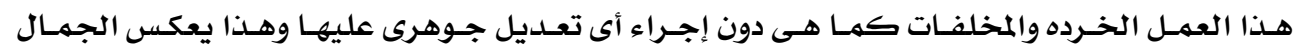

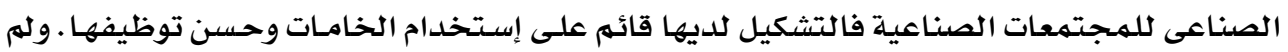

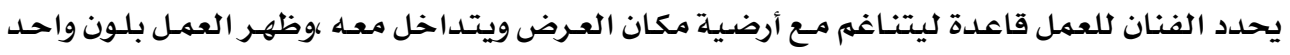

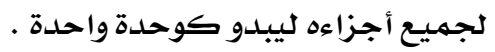

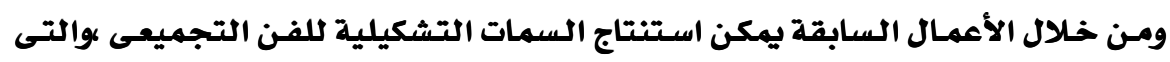
بمثابة الأسس والمعاير التى يتم على أساسها بناء العمل التجميعى وهى الاعهي:

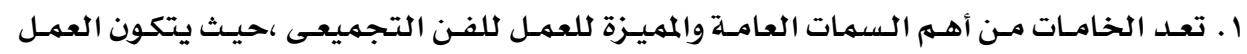

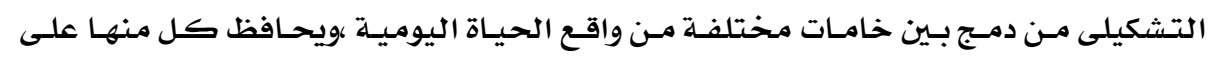

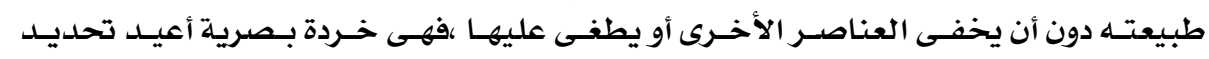

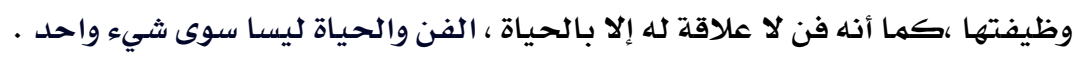

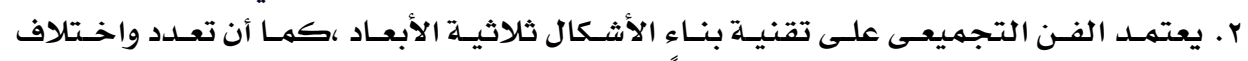

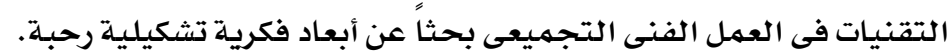

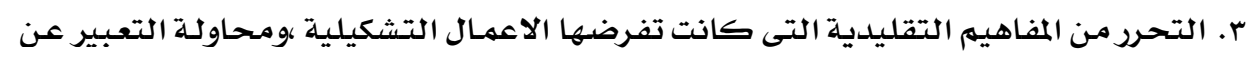

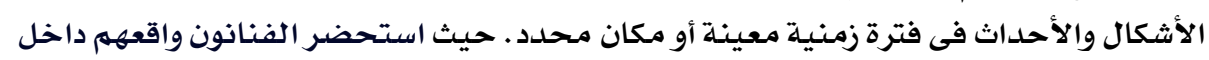
أعما لهم الفنية.

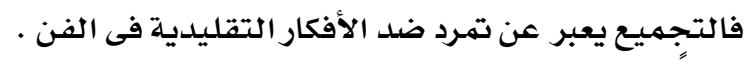

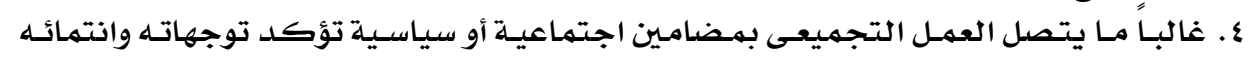

$$
\text { الوطنى. }
$$

ه. يدعم فن التجميع الاتجاه الفكرى التجريبى من تجزئ فكرى وإعادة تركيب بنائى فنى.

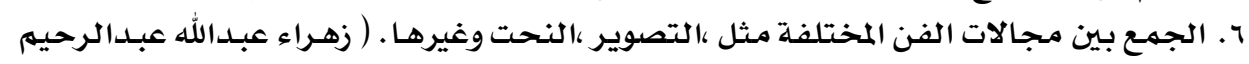

(rr: r..人:

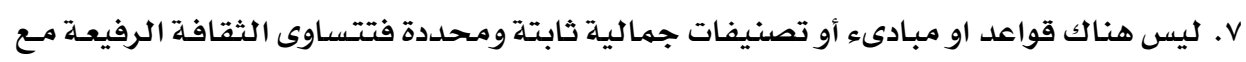

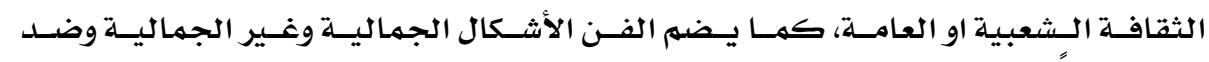

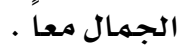

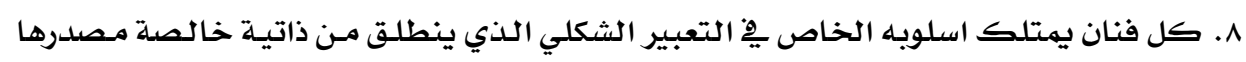

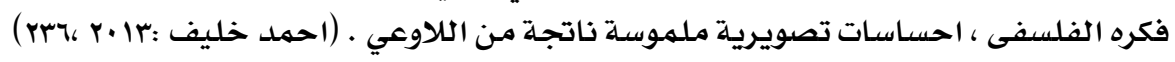

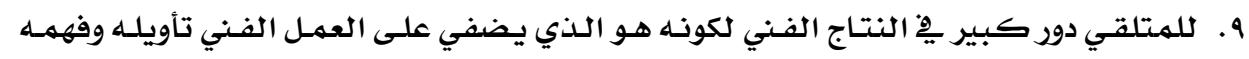

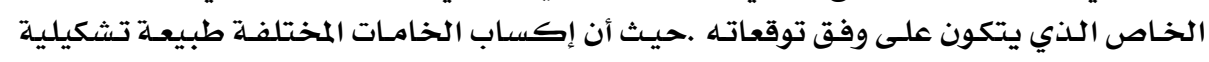

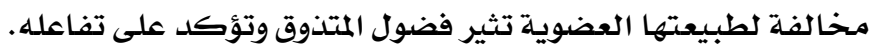


• ا ـ يعتمد اسلوب التلوين على الفكر التجريـدى وإعطاء مسطحات لونيـة مختلفـة تشبـة الطلاء

تعبر عن مضمون الفكرة .

11. تحطيم إطار الصورة بإضافة المجسمات خارج إطار العمل التشكيلى وذلك الكئ لتحقيق التواصل

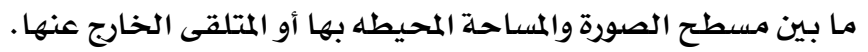

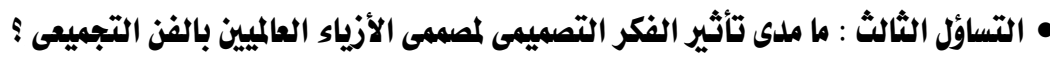

من خلال تحليل لأعمال مصمهى الموضدة والازيـاء التجميعيـة ،وجـــ البـاحثة أن أقواهم أثراً

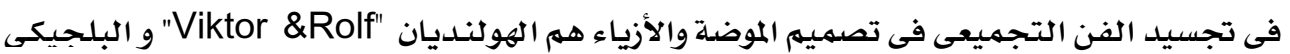

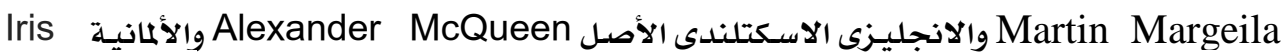

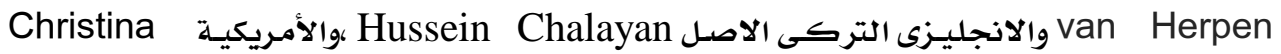
Chalmers

\section{: (1979) Viktor \&Rolf" -}

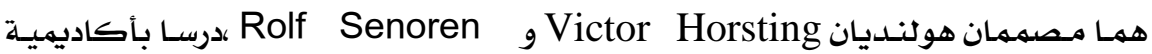

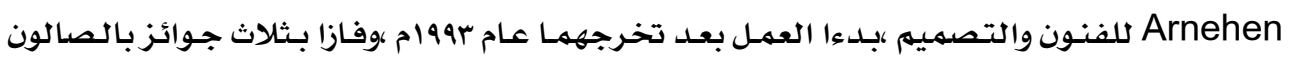
الأوروبى Salon Europeen des Jenunes Styliste في فرنسـا .انتقلا الى بـاريس وقدمامـا أربعـة

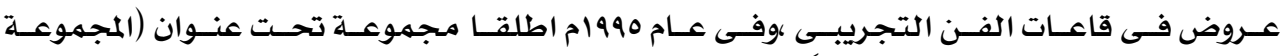

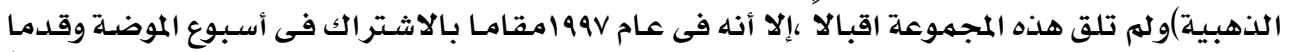

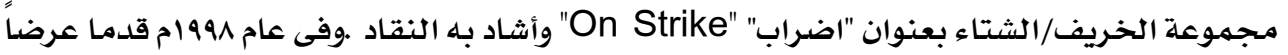

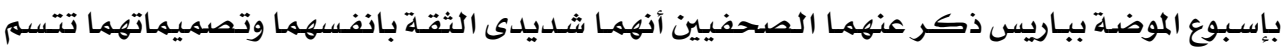

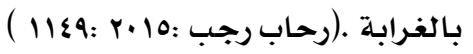

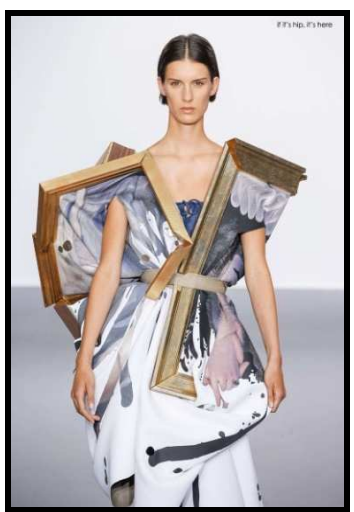

(ir)

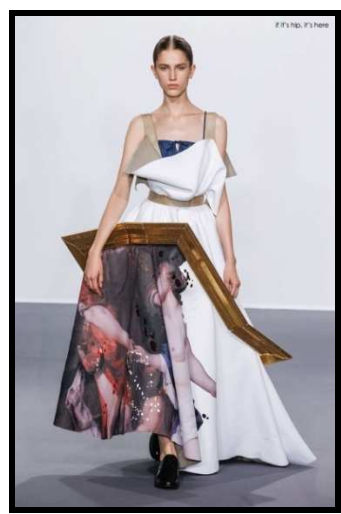

(II)

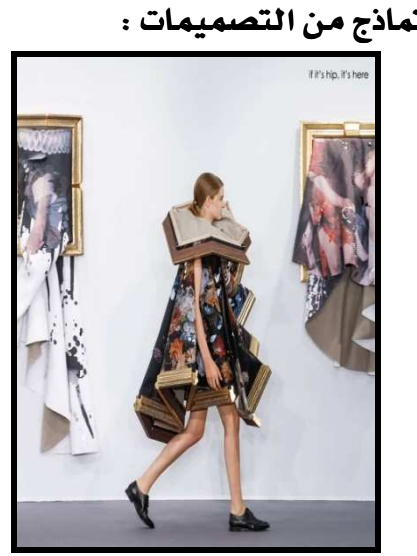

(1.)

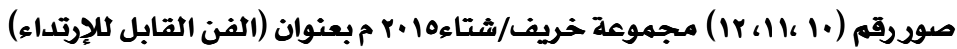
https://www.pinterest.com/pin/147915168988375714 


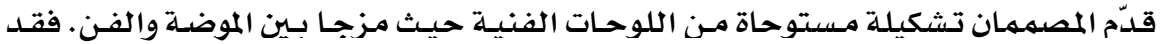

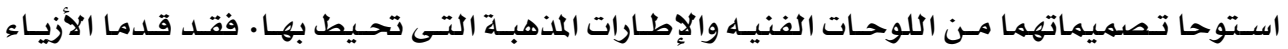
والعارضات على انهما لوحات فنيـة متحركهـ ،وأكدا على ذلك بـاسـتخدامهما لإطـارات مـن الخشب

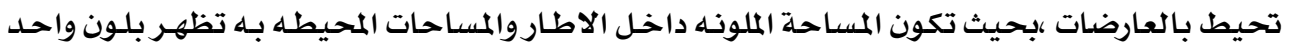
للتأكيد على الفكرة وابرازها ،وجذب النظر الى المساحات الملونه وجعلها هى بؤرة العهل الفنى. وظهر فى هذه التصسميمات الخطوط الحـادة كالخط المستقيهم المائل والمنكسـر بشكل واضـح ولكن قلل مـن

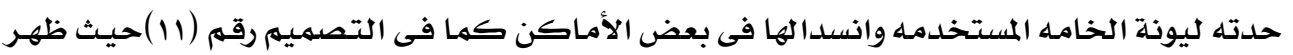

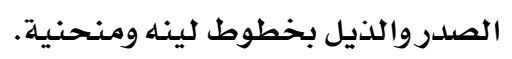
تفسير البناء التشكيلى :

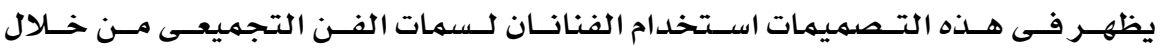
استخدامهما لخـامـات جاهزة ،وهى اطارات الخشب المذهبـة التى تحيط بـاللوحات الفنية لتعطى البعـد الثالث الحقيقى .كما أنهما أعطا مسـاحات لونية تبدو على شكل ضربات فرثـاة ملونة بشكل عشوائى

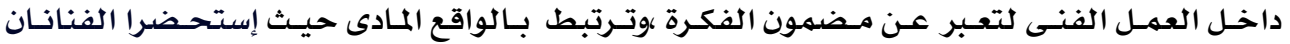
واقعهما داخل تصهيمـاتهما الفنيـة .وظهر هذا الواقع بشكل رمـزى خيالى ،لا يتقبـل المجتمـع ارتدائه فى مناسبـات الحياة الإعتيادية ولذلك تتخذذ هذه النوعية من التصميهـات صفة "أزياء الفانتازيا"

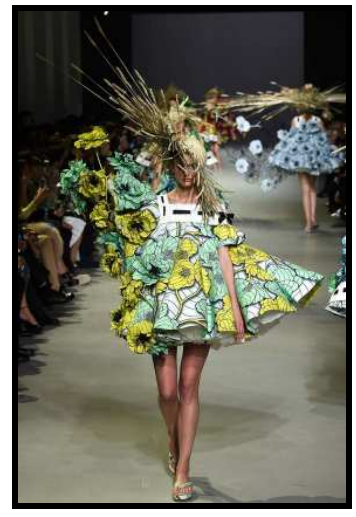

(10)

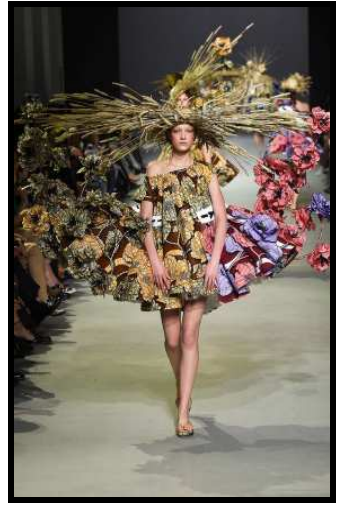

(1६)

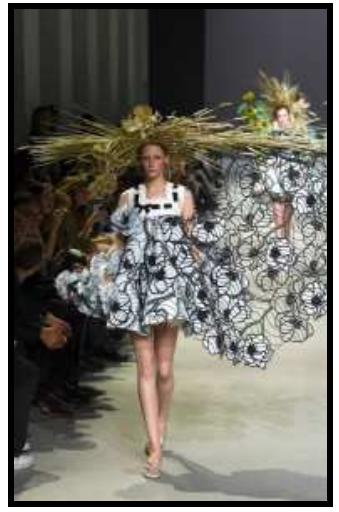

(ir)

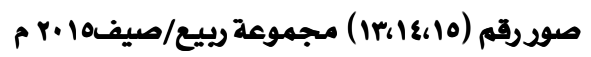

http://www.vogue.com/fashion-shows/spring-2015-couture/viktor-rolf تحليل التصميمات : تتكون التصميمـات من فسـاتين واسعـة جـرسية الشكل مزينـه برسـومات ورود ونبـاتـات بأحجـام

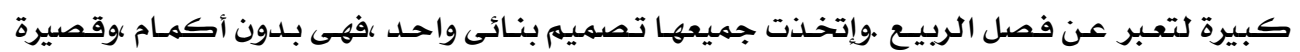


وواسعة بها قصة عرضـية أعلى خط الصدر ظهرت بلون أبيض سـادة فى التصميمـين رقمى (rاء، 10 )

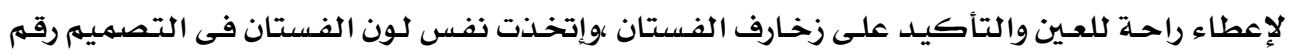

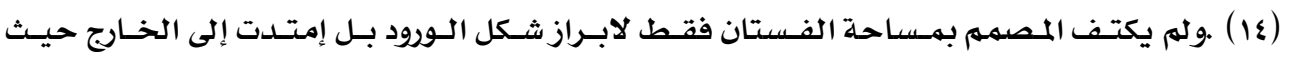

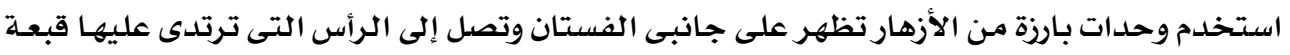

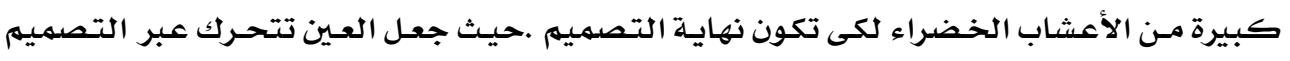

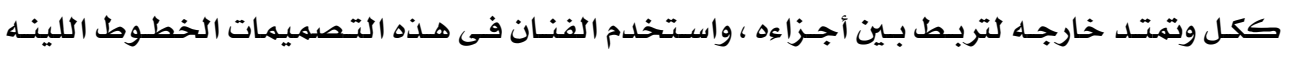

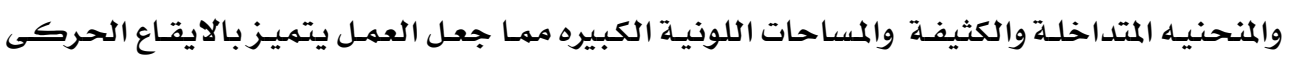

$$
\text { السريع }
$$

تفسير البناء التشكيلى :

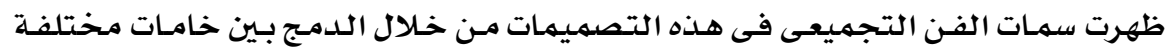

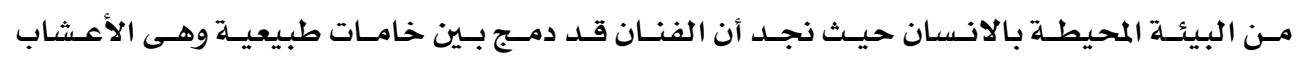

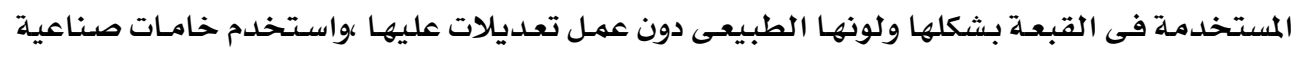

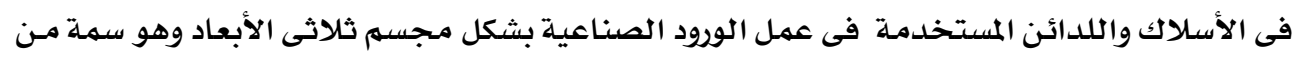

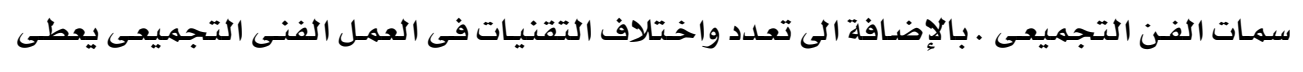

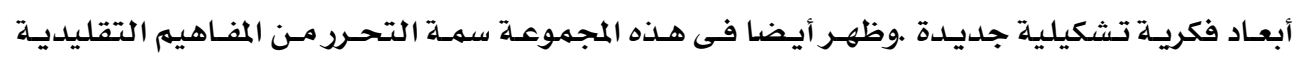

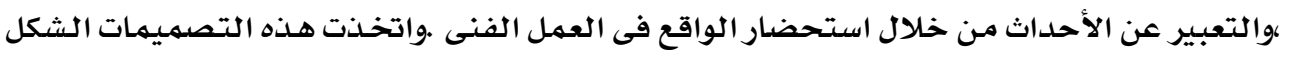

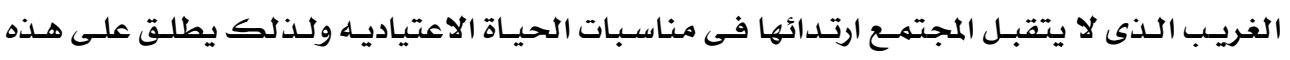

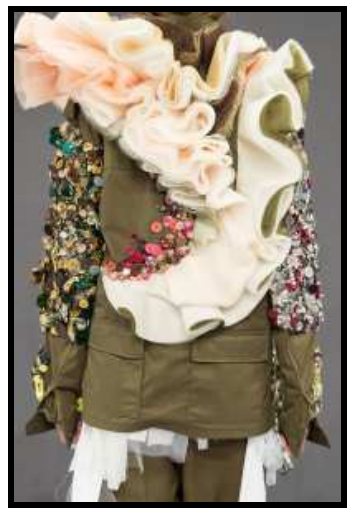

(in)

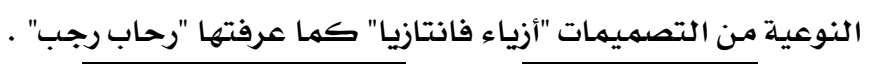

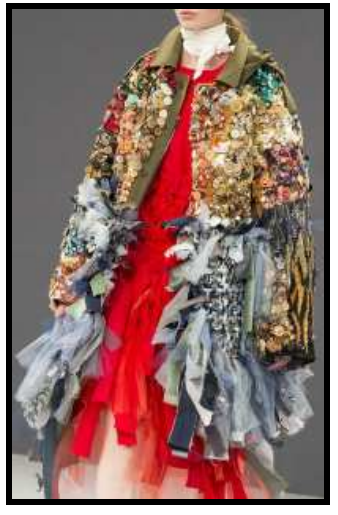

(iv)

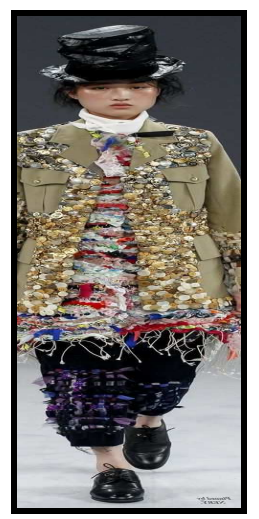

(17)

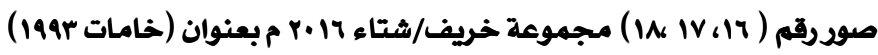

http://www.vogue.com/fashion-shows/fall-2016-couture/viktor-rolf 


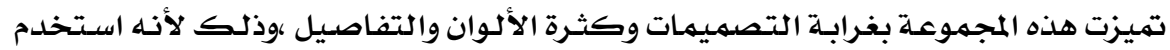

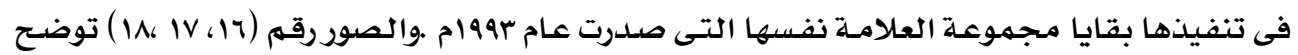

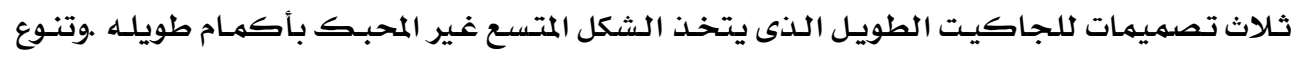

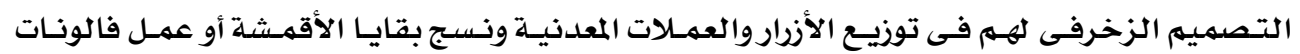

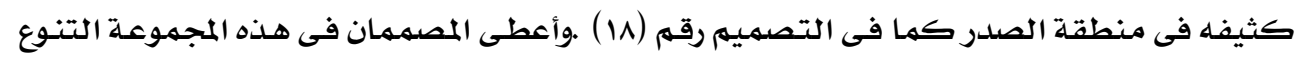

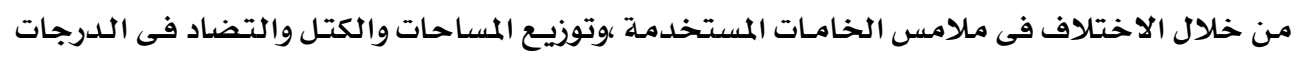

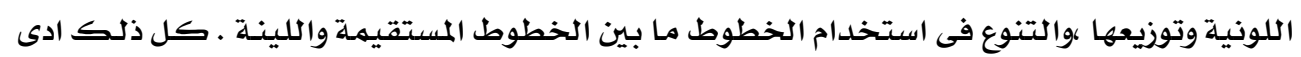

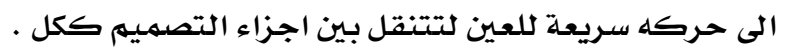
تفسير البناء التشكيلى :

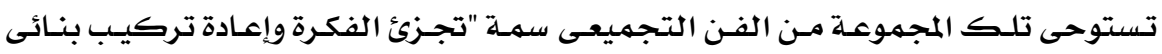

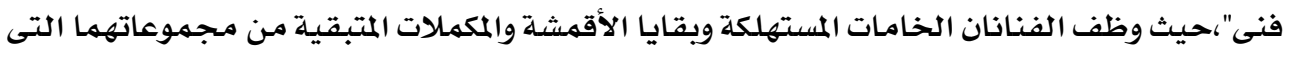

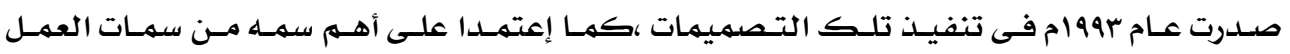

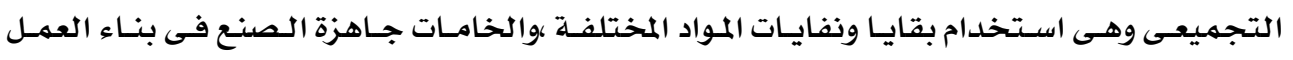

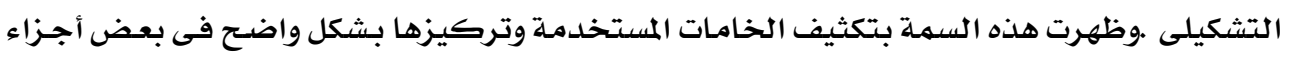

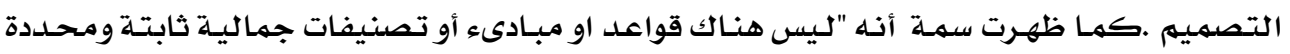

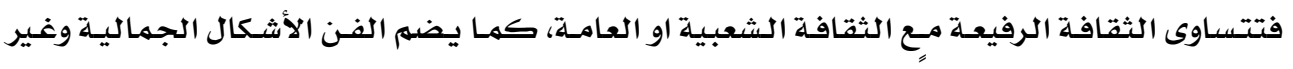

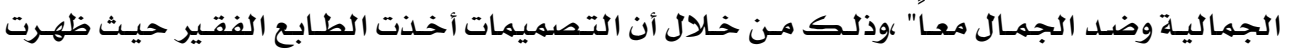

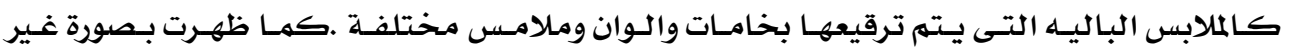

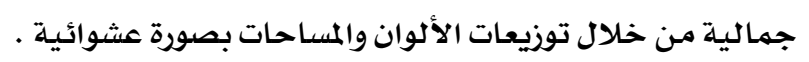
: (م) Martin Margiela -

هـو مـصمهم أزيـاء بلجيكى ،تخـرج مـن الأكاديميـة الملكيـة للفنـون الجميلـة Antwerp عـام

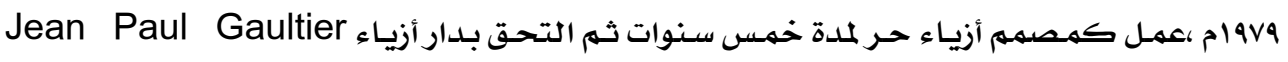

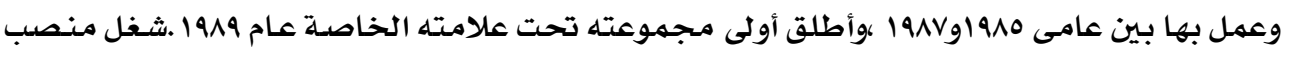

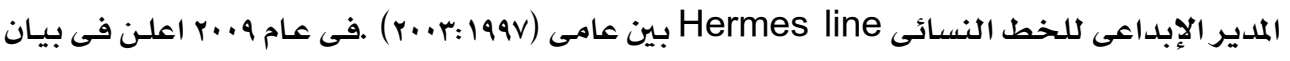

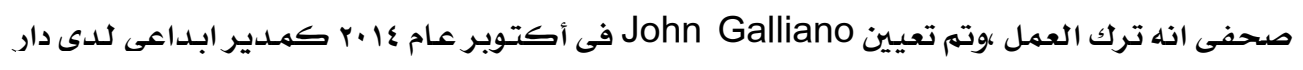

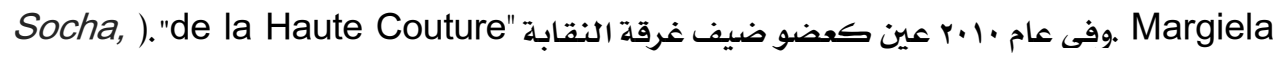
(Miles:2014 


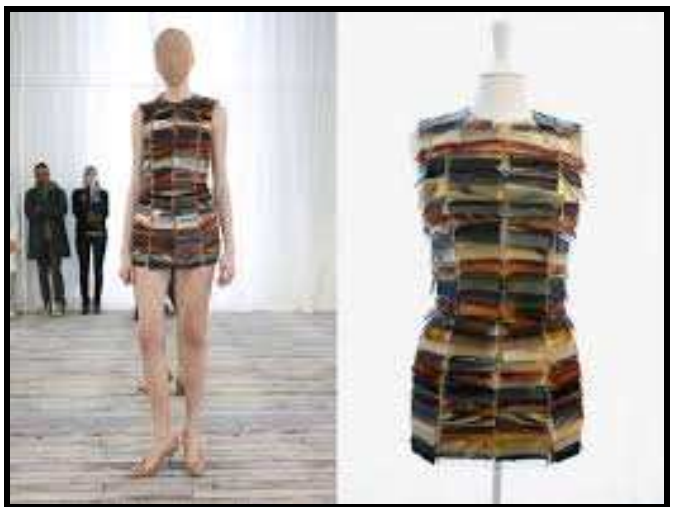

نماذج من التصميمات :

صورة رقم (19)

Margiela فستان من تصميم بيت أزياء

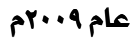

" Comb dress أطلق عليه فستان المشط"

http://www.todayandtomorrow.net/

2009/02/10/maison-martin-

/margiela-artisanal-2

تحليل التصميم :

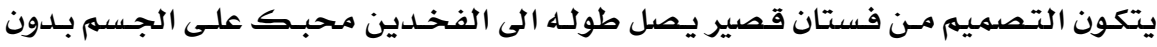

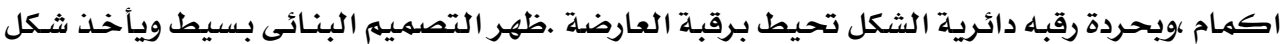
الجسم وذلك للإبراز التصميم الزخرفى الذى يعتمد على تثبيت صفوف متتاليـة مـن أمشاط الشعر

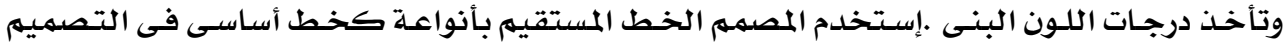

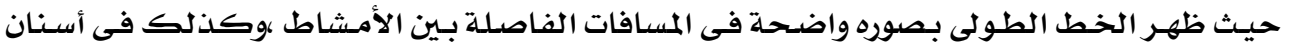

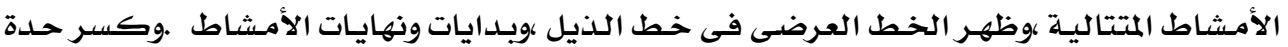

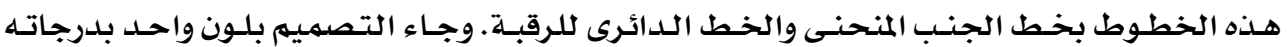

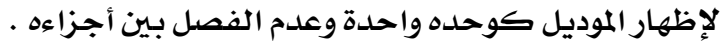

تفسير البناء التشكيلى :

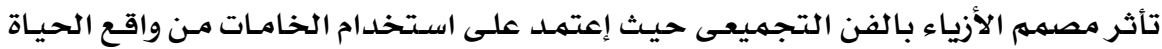

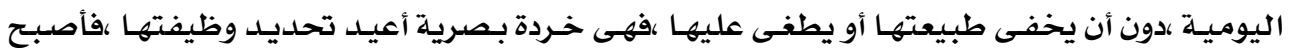

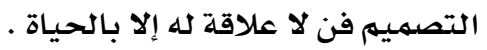
(م)१v.): Hussein Chalayan ولد حسين تشاليان فى مدينـة نيقوسيا وهى عاصـمـة قبرص ،إنتقـل إلى إنجلـترا مـع أسـرته

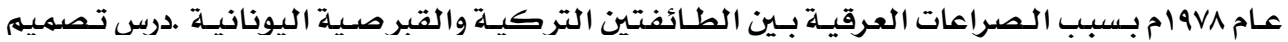

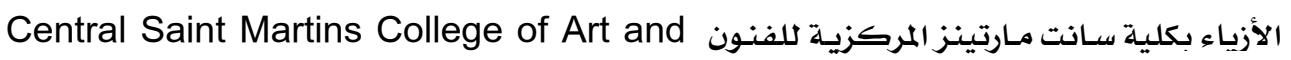

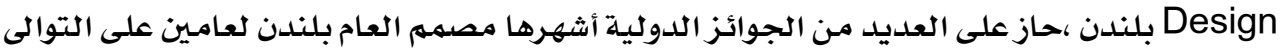

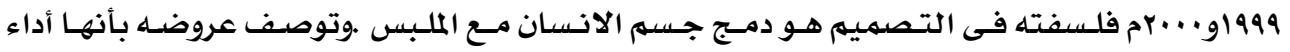
بالدرجـة الأولى ،وفى بعض الحالات توصف بأنها "فن يمكن ارتداءه" . http://en.wikipedia.org/wiki/Hussein_Chalayan 

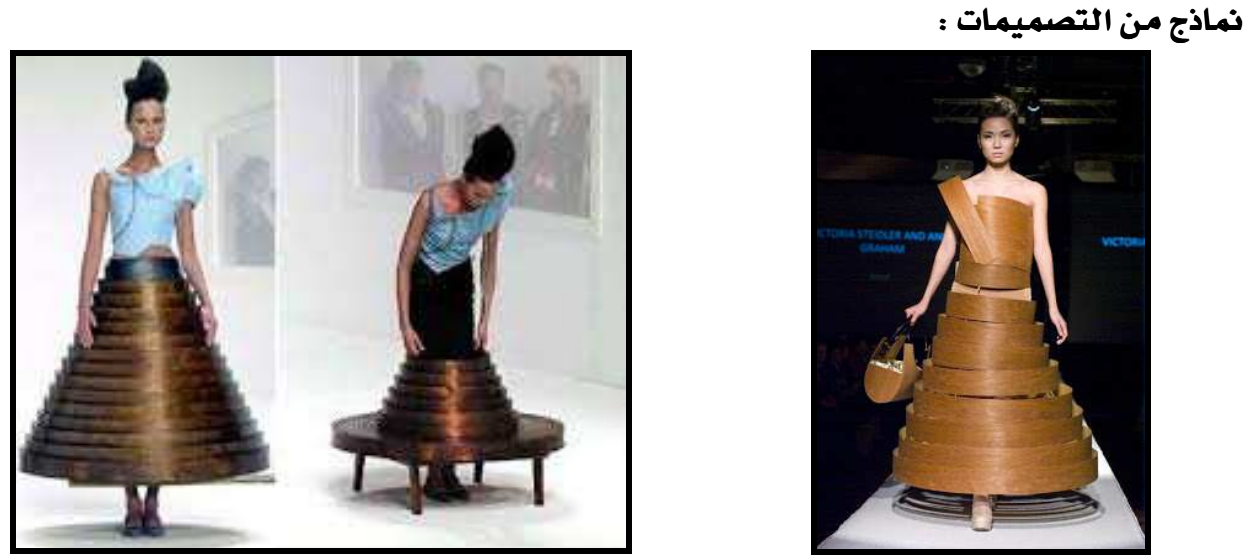

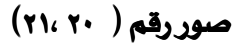

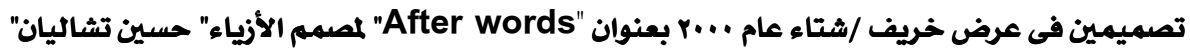

تحليل التصميمين :

استخلدم المصمم فى تنفيذ تلك التصميمات رقائق من الخشب والذى كان الهدف منها هـو

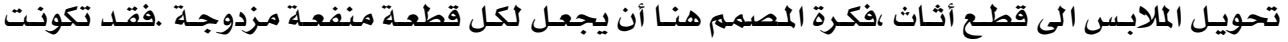

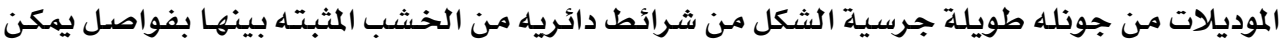

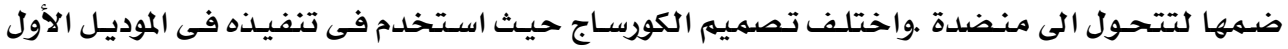

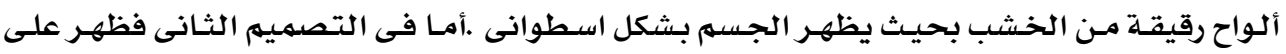

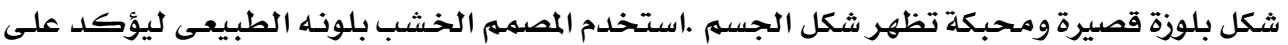

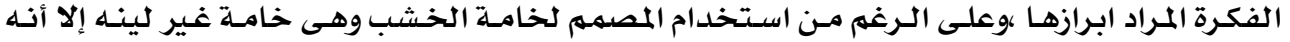

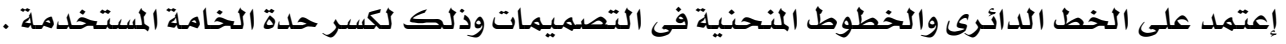

$$
\text { تفسير البناء التشكيلى : }
$$

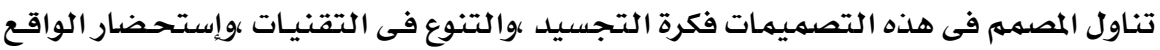

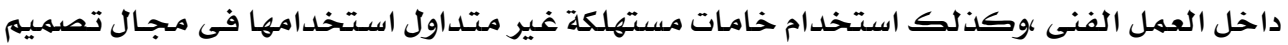

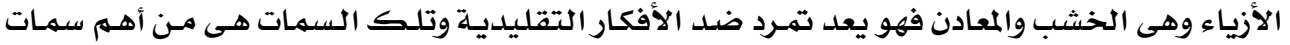

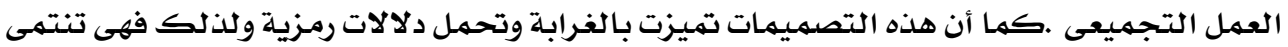
لأزياء الفانتازيا.

\section{(م/9६^) Christina Chalmers -}

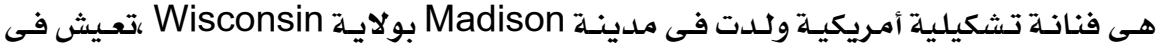

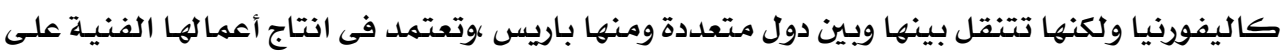

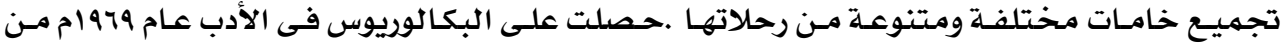


جامعـة Lowa والماجستير عام عدوام مـن كليـة Rudolph Steiner بكاليفورنيا .فلسفتها الفنيـة

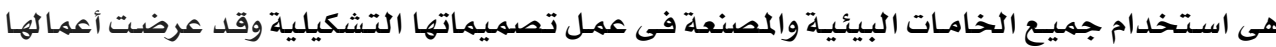

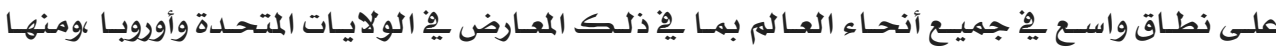

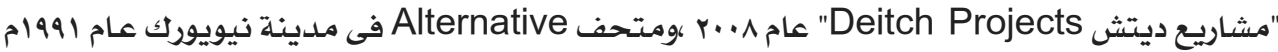

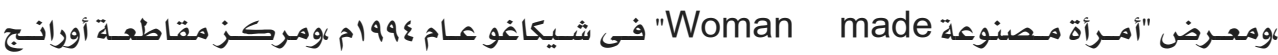

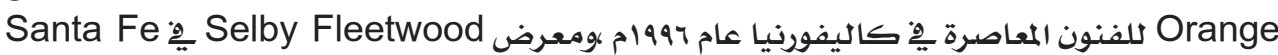

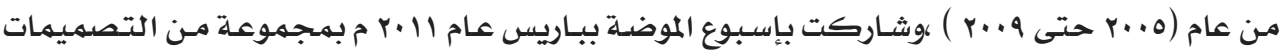

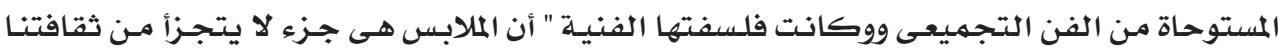
ولذلك فهى تتأثر بصورة كبيرة بالفن والعكس التهي ووست فالعكس" .

http://www.selbyfleetwoodgallery.com/artists/christina_chalmers___paintings
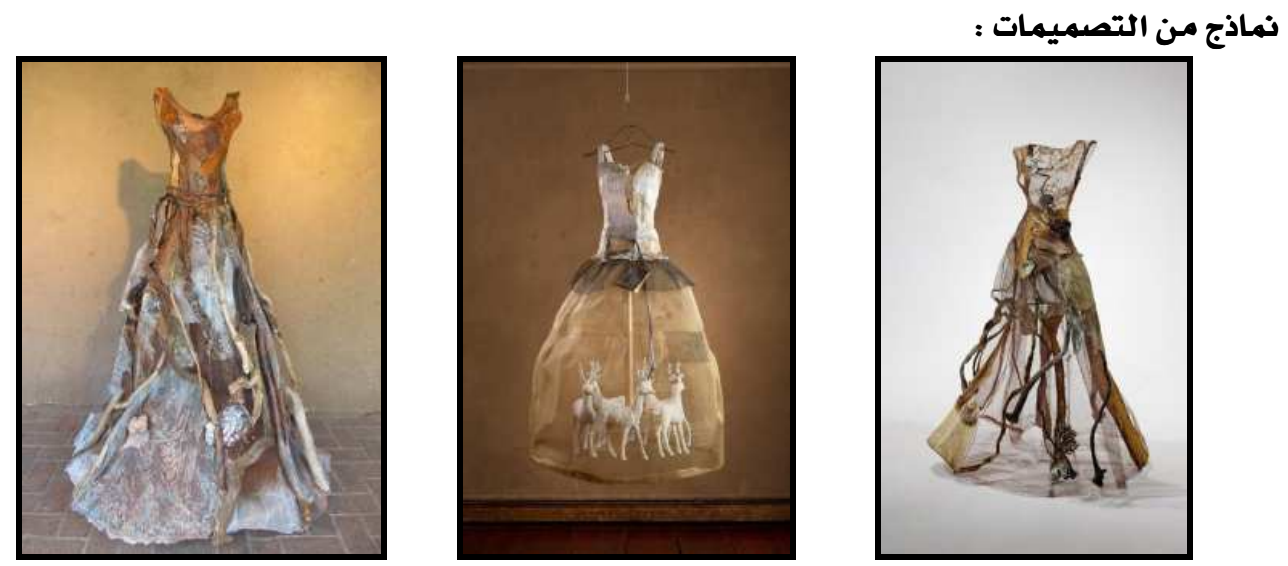

صورة رقم (r\&، rrr (r)

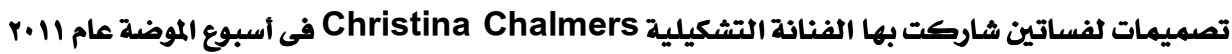
http://artsyforager.com/2011/10/06/deconstructing-beauty تحليل التصميمات :

هـ مجموعة مـن الفساتين اطلقت عليها الفنانـة اسهم "Assemblage dress " تأخـذ

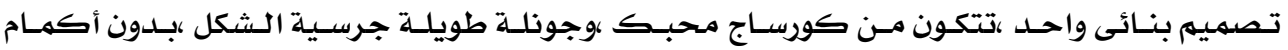

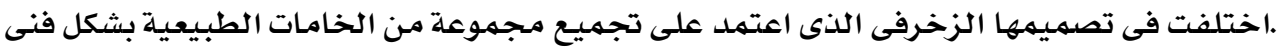

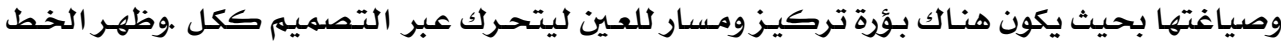

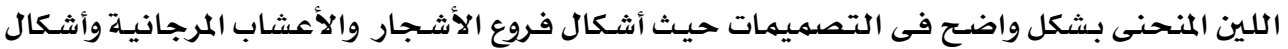

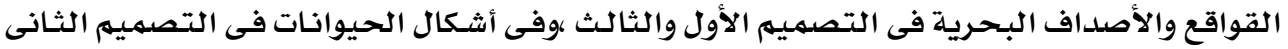


واستخخدمت المصممة الألوان الترابيـة فى تصميماتها لتعبر عن الطبيعـة فاستخلدمت درجـات البيـج.

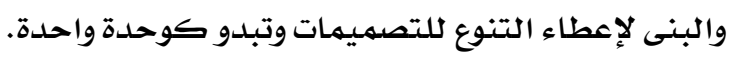
تفسير البناء التشكيلى :

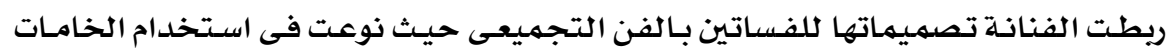

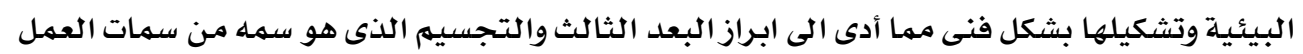

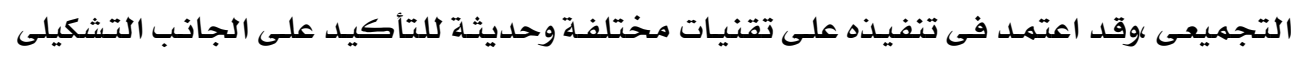

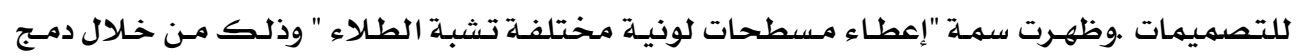

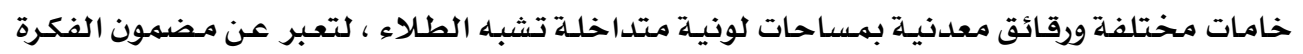

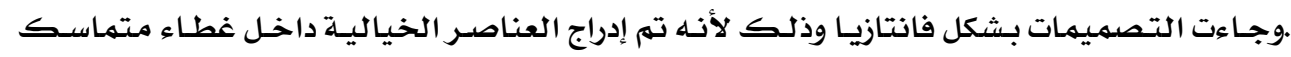

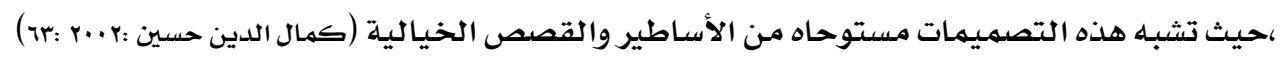
: r.1.: 1979) Alexander McQueen -

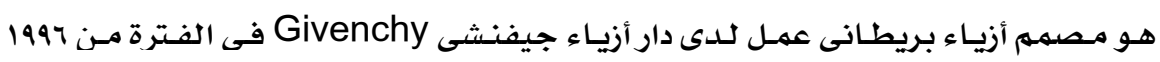

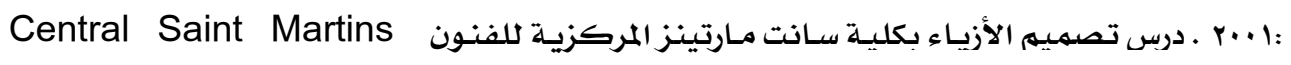
ملبندن College of Art and Design

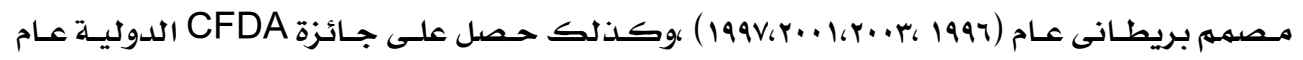
(https://en.wikipedia.org/wiki/Alexander_McQueen) .r..r
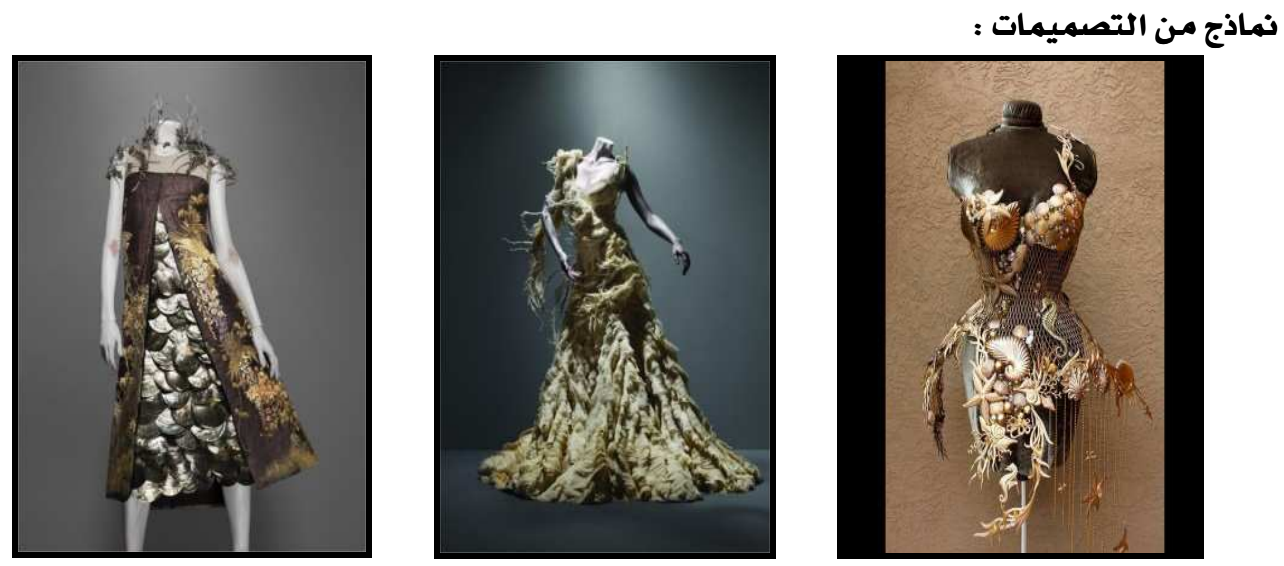

$$
\begin{aligned}
& \text { صور رقم (rV، r7،ro ) } \\
& \text { تصميمات لعرض "الكسندر ماكوين" صيف /ربيع عام ب..r }
\end{aligned}
$$

http://www.nytimes.com/2011/05/03/fashion 
تحليل التصميمات :

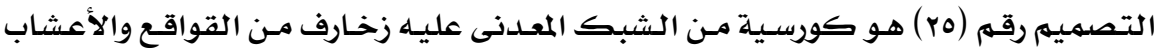

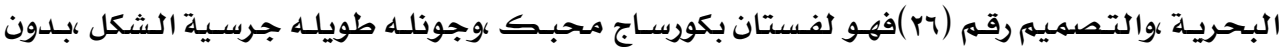

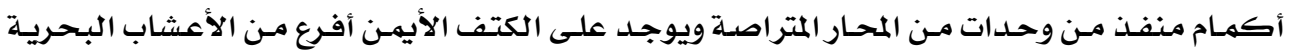

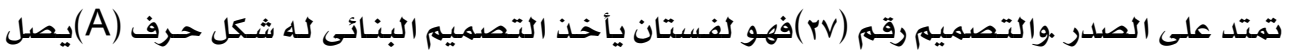

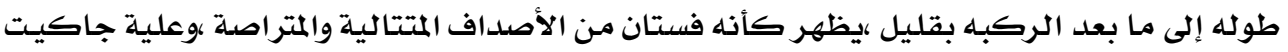

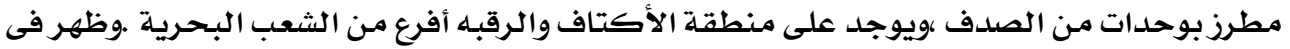

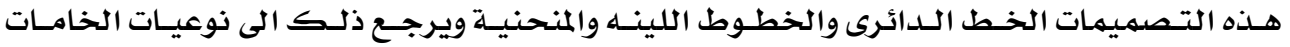

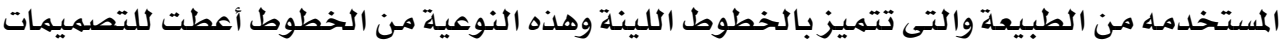

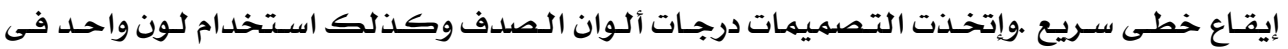

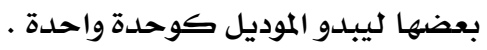
تفسير البناء التشكيلى :

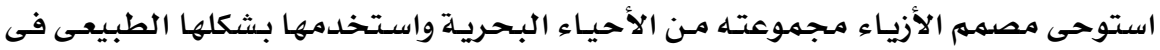

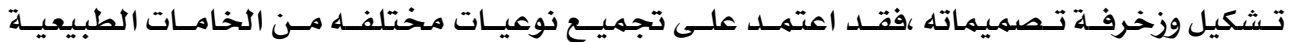

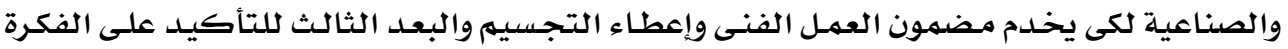

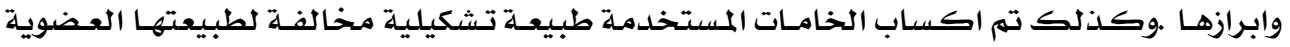

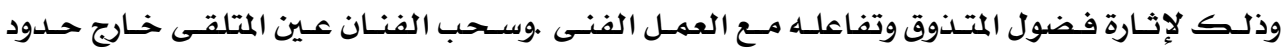

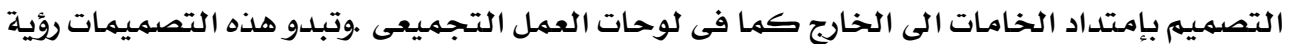

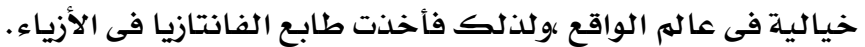

\section{الأسس التى تم التوصل اليها من خلال تحليل أعمال مصممى الأزياء :}

ا ـ الدمجج بين خامـات مختلفة من واقع الحياة اليومية سـواء أكانت خامـات طبيعيـة أو صسناعية ،

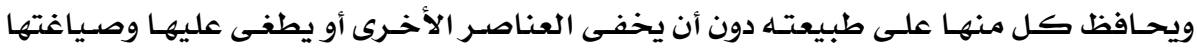

$$
\text { بشكل فنى. }
$$

r ـ اظهار البعد الثالث باستخلدام الخامـات مجسمـة كمها تبدو في الطبيعة.

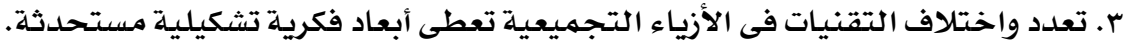

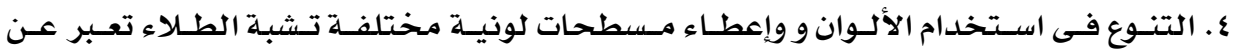

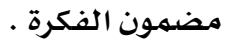

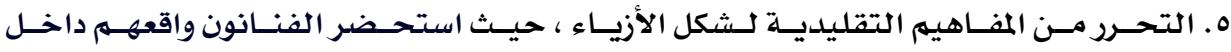

$$
\text { أعما الهم الفنية. }
$$

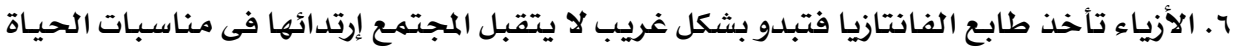
الاعتيادية. 
• التساؤل الرابع : ما امكانية تقديم مقتزحات تصميمية لأزياء تندرج تحت مسمى الفاتتازيا مستوحاة من سمـات

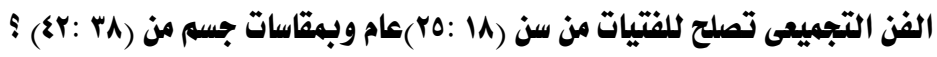

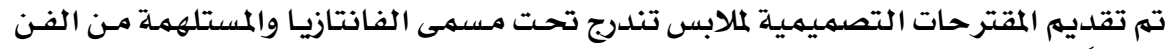

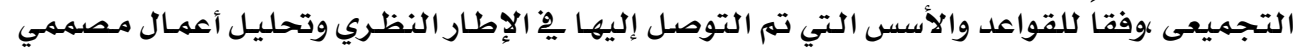

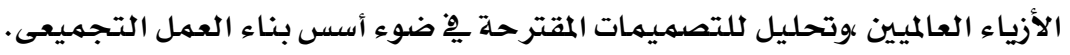

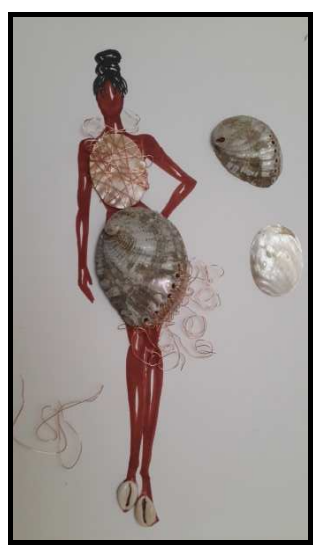

تصميه رقم (1)

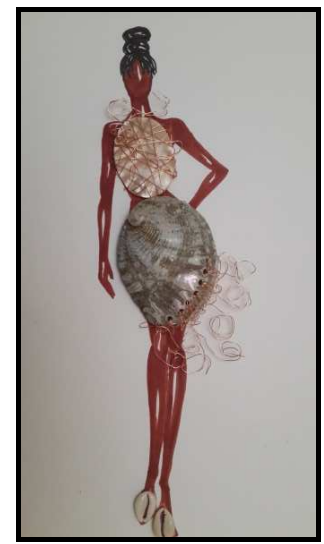

الخامات المستخلدمة : صدف ،سلك ،قواقع بحريه.

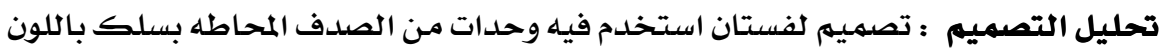

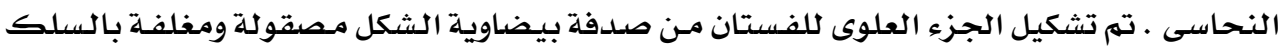

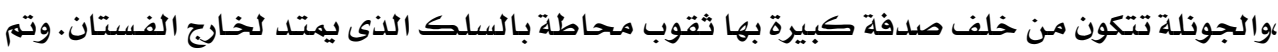

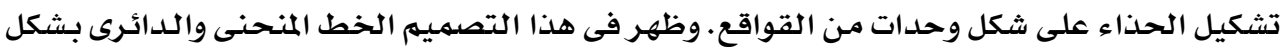

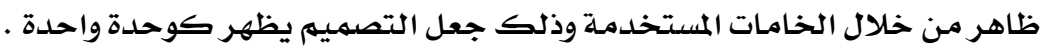

تفسير البناء التشكيلى : ظهرت سمـات الفن التجميعى مـن خـلال استخدل فام خامـات بيئيسة

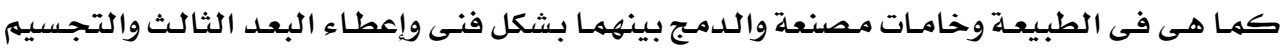

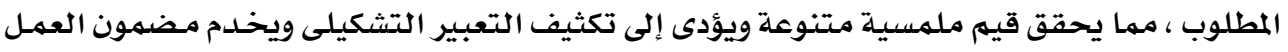

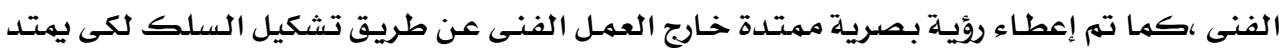

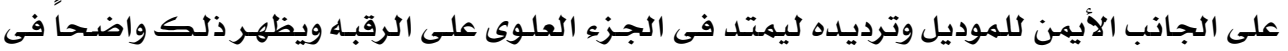

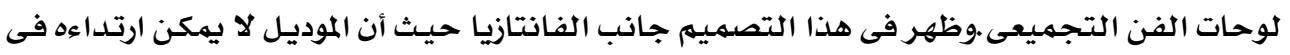

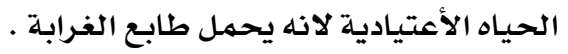




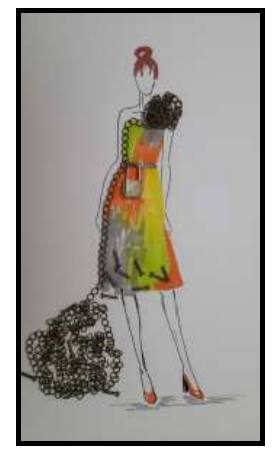

تصميم رقم (『):

الخامات المستخدمة : ألوان ،سلاسل ،مسامير ،قفل

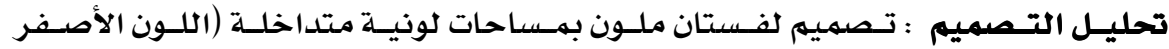

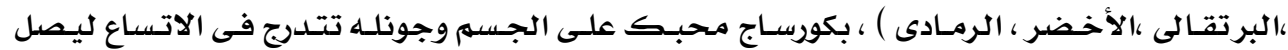

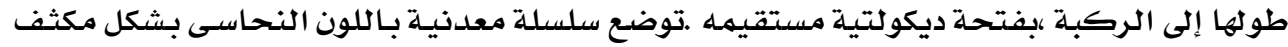

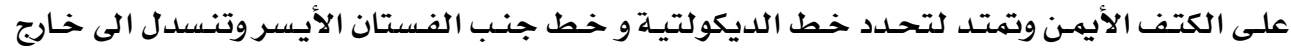

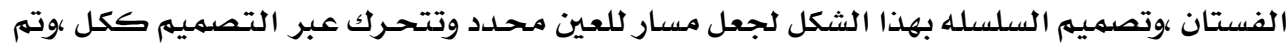

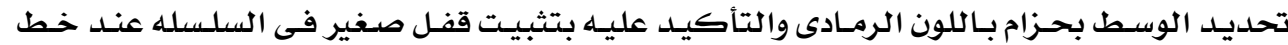

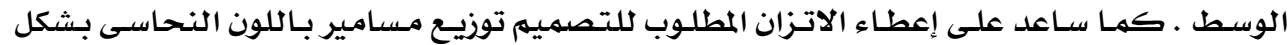

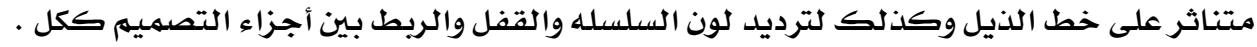
تفسير البنـاء التشكيلى : إتبـع فى هـذا التصميم سمهـة "إعطـاء مسطحات لونيـة مختلفـة

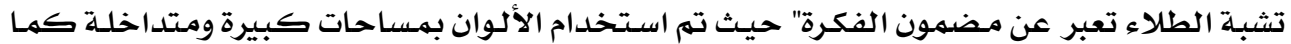

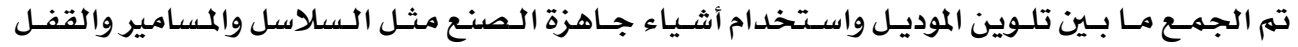

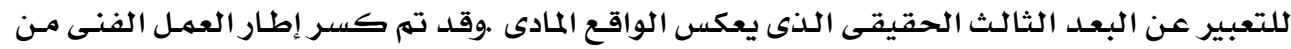

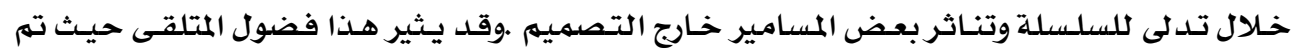
اكساب الخامات طبيعة تشكيلية مخالفة للواقع. تصميم رقهم (ז) :

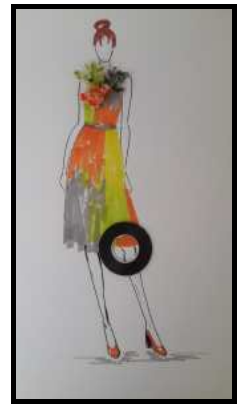


الخامات المستخدمة :ألوان ششعاب بحرية ، اطار

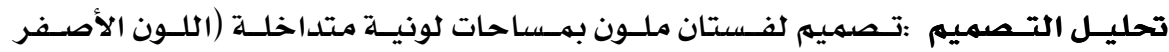

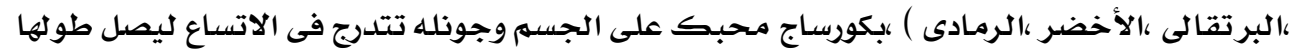

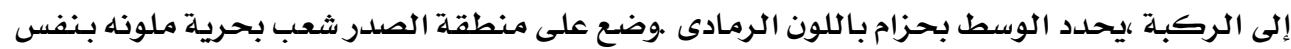

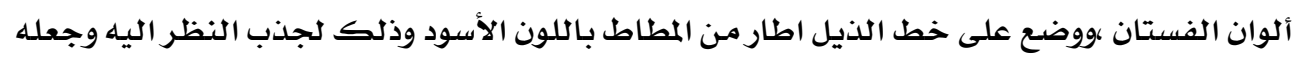
بؤرة العمل الفنى والتأكيد على فكرة امتداد الفكرة خارج اطار العمل الفيل التشكيلى.

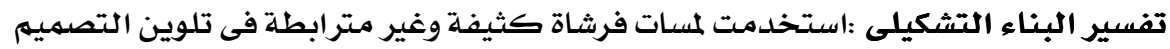

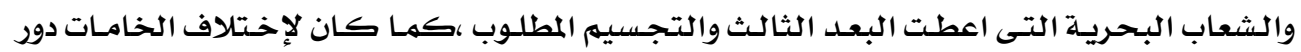

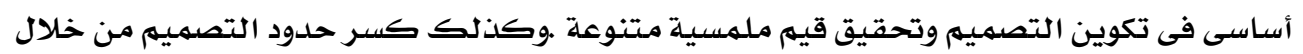

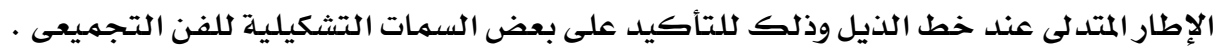
تصميه رقهم (צ) :

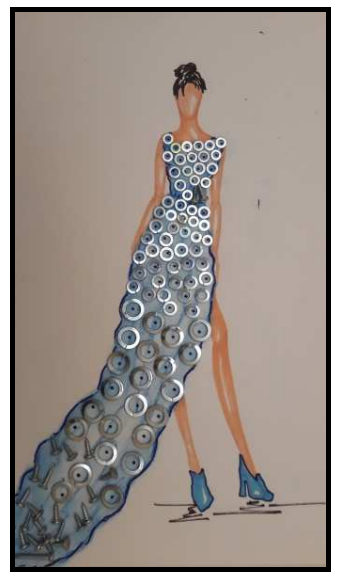

الخامات المستخدمة : ألوان ،إطارات معدنية دائرية الشكل فضية اللون ،مسامير ،خرز

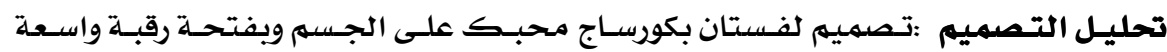

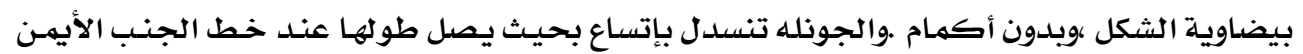

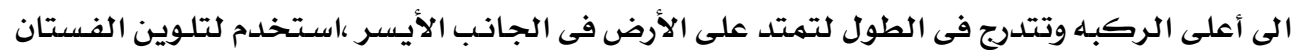

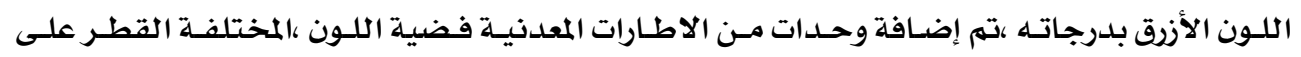

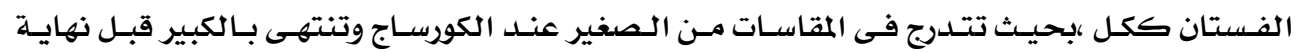

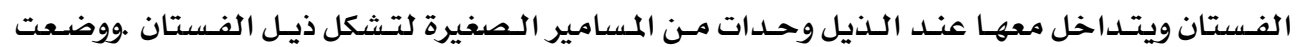

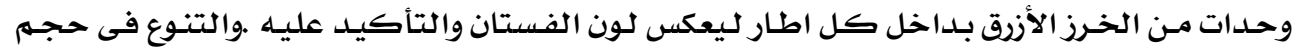

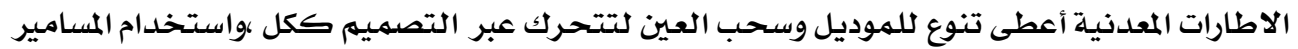

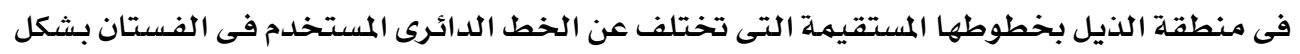


$\overline{\underline{2}}$

واضدح أكل على نهاية الفستان وجعل العـين تنجذب اليها ليربط المتلقى بـين اجـزاء التصهيهم بعضها البعض.

تفسير البناء التشكيلى_اعتمـد هـذا التصميهم على الخـامـات المصنعة والمستهلكة مـن واقـع

الحياة اليوميـة حيث تم اعادة تحديد وظيفتها لكى تثير فضول المتلقى وتؤكد على تفاعلـه .كما تم الجمـع ما بين المسطح والمجسمى فى التصهيهم وذلك لإضافة البعد الثالث الحقيقى للعمل الفنى. : تصمييم رقمر (0)

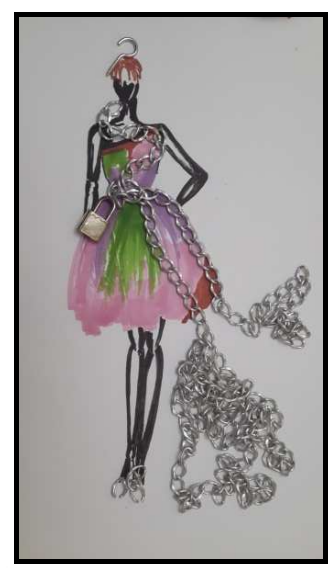

الخحامات المستخدمة :ألوان ،سلاسل فضيـة اللون ،مسـامير ، قفل

تحليل التصميم :تصميهم لفستان بكورساج محبـك على الجسهم وبفتحة رقبـة واسعة تهتـد بشكل مـائل من الكتف الأيهن الى أسفل الإبط الأيسر ،وبلدون أكمام .والجونله جرسيـة الشكل يصل طو لها إلى مـا قبل الركبـة بقليل ،استخلدم لتلوين الفستان الألوان (التوردى والموف والاخخـر والبنىى) بهسطحات لونية كبيرة ومتداخللة وجعل اللون البنى على خط الذيل فى الجههـ اليهنى وعلى خط

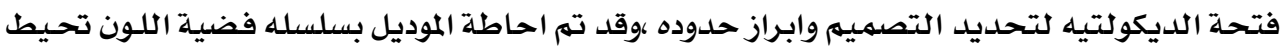

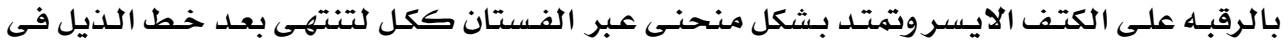

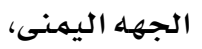

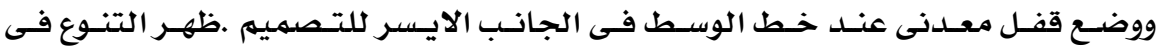

التصميهم مـن خلال التنوع فى الخطوط والمسـاحات اللونية ،ولمعـة الخامـات المستخدمة وتبـاينها.

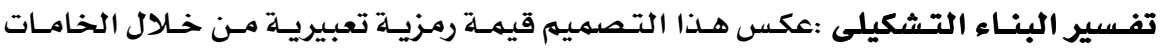
المستخدمـة ،والذى يعد تهـرد ضد الأفكار التقليديـة للفـن ،كمـا ظهرت ضـربـات الفرشـاه الملونـة بشـكل عشوائى داخل التصهيهم .وقد ارتبط فى جزء منـه بـالواقع المادى مـن خـلال استخدام خامـات حقيقيـة تحقق عنصسر التجسيه والبعد الثالث الحقيقى ،كما خرج عن حدود التصميهم بإمتداد السلاسل على جانب الموديل . 


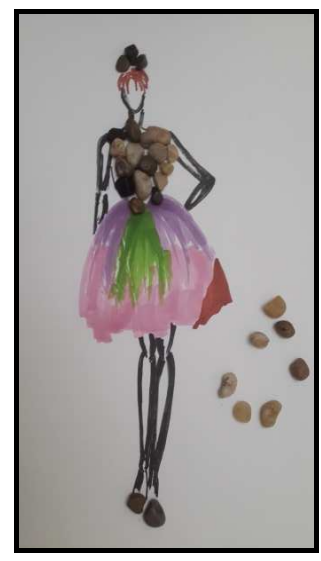

تصميم رقم (7):

الخامات المستخدمة :ألوان ،حجارة

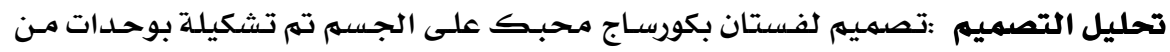

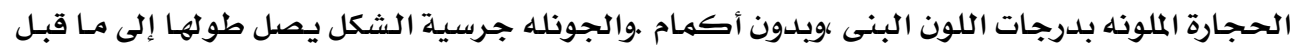

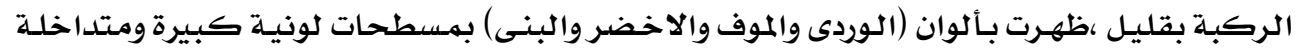

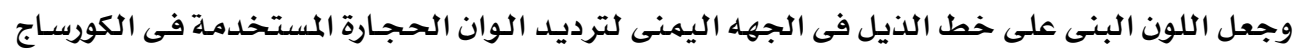

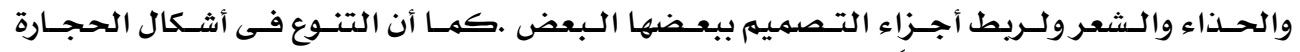

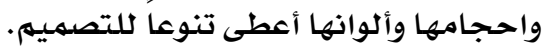

تفسير البناء التشكيلى :تم الجمع بين المسطح والمجسم فى التصميم لإضافة البعد الثالث

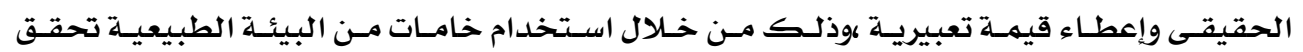

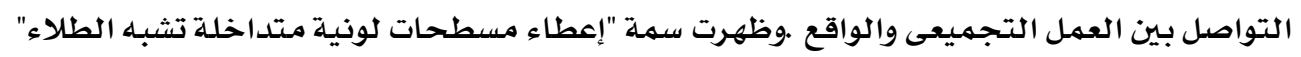

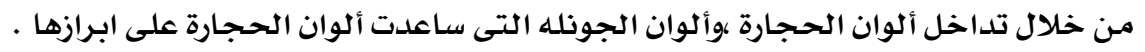
تصميم رقم (๖):

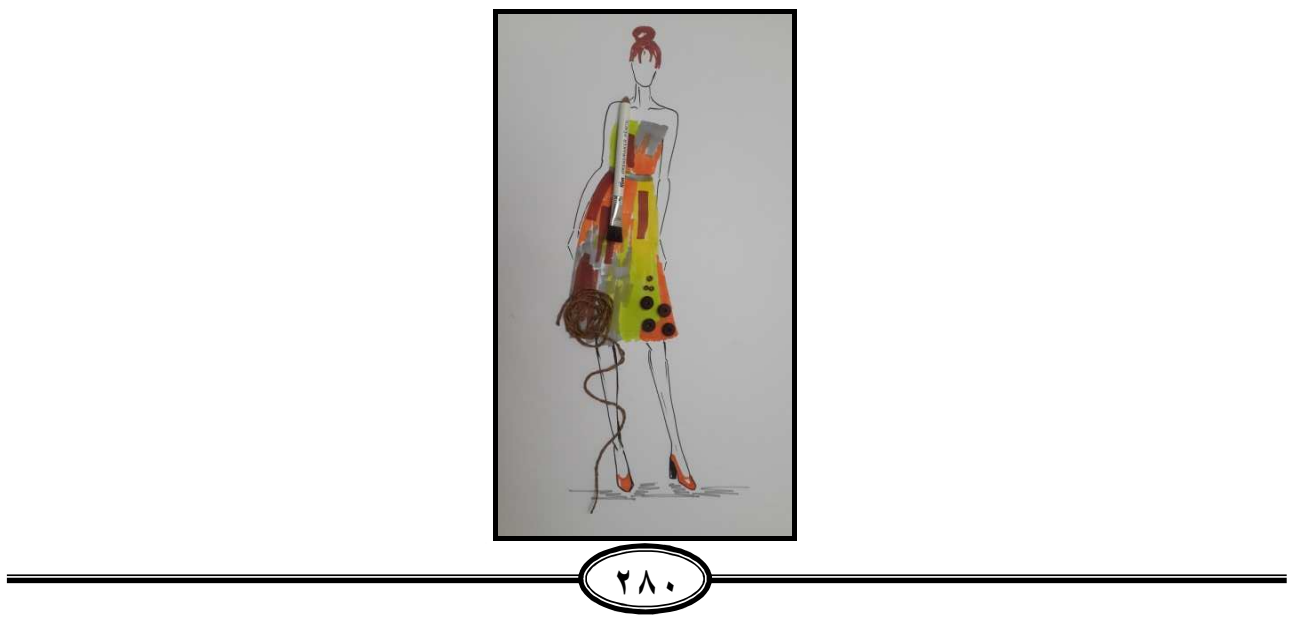


الخامات المستخدمة :ألوان ،خيط دوبار ،اخشاب ،خرزبنى ، فرشاة تلوين ·

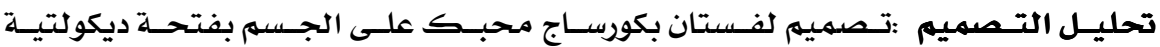

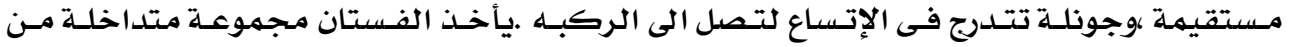

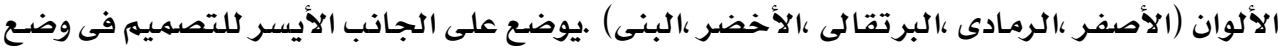

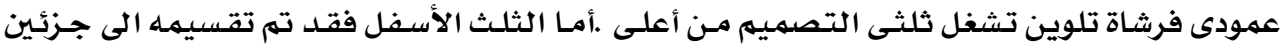

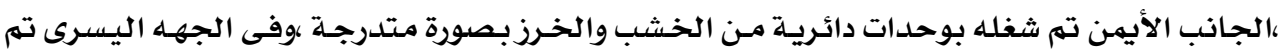

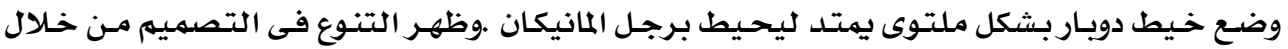

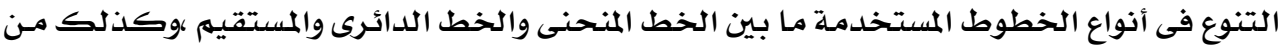

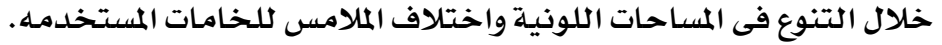

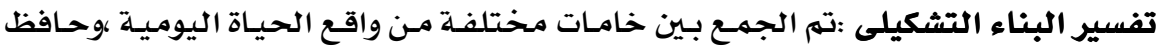

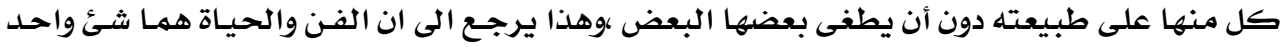

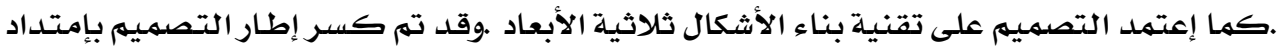

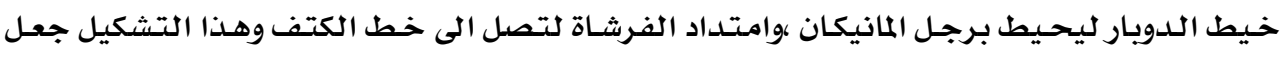

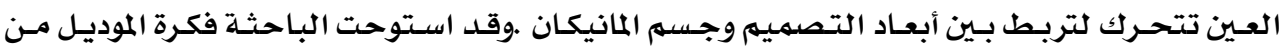
اللوحة رقم ( ) التى تحمل فكر الفانتازيا .

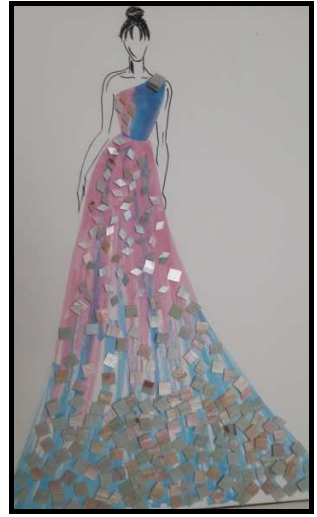

(1.)

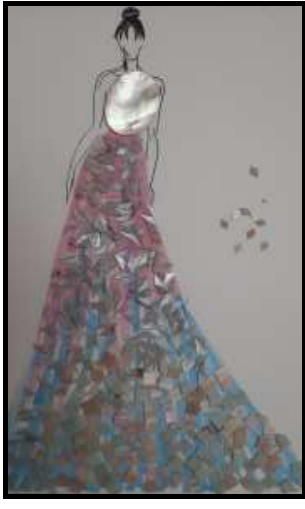

(4)

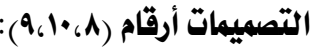

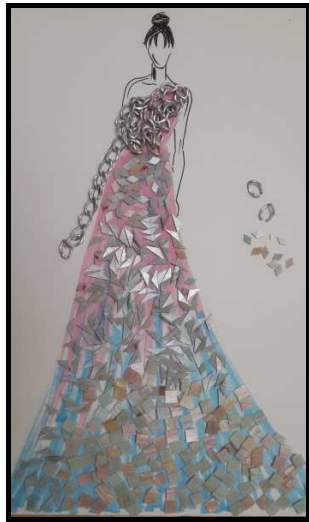

(

الخحامـات المستخحلمـة :سلاسـل فضيـة ،قطـع مـن البـلاسـتيك مقطعـة على شـكل مـريعـات ومثلثثات بالللون الرمادى والوردى ،صدف

تحليل التصميمات :تصميم لفستان بكورساج محبك على الجسهم بفتحسة ديكولتيـه مائلسه

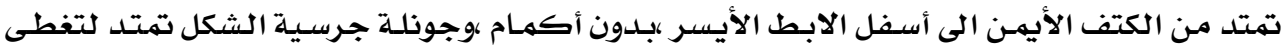

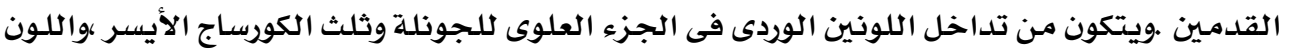




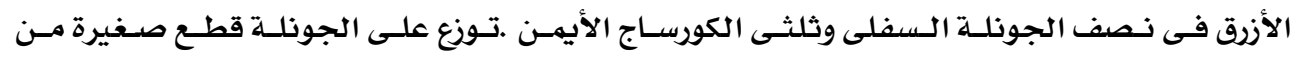

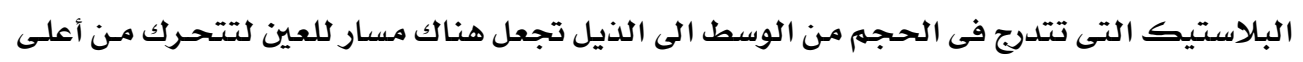

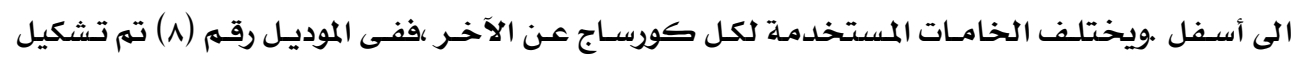

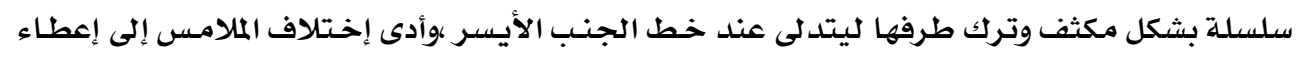

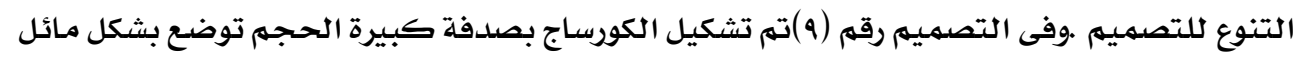

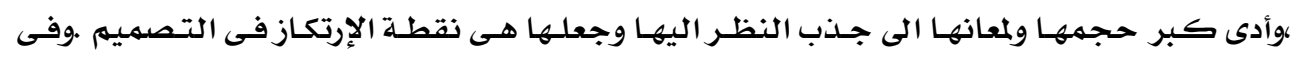

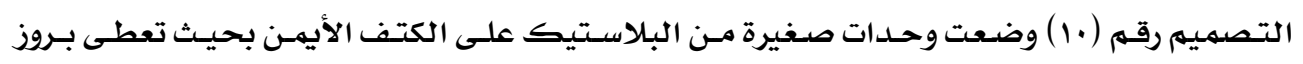

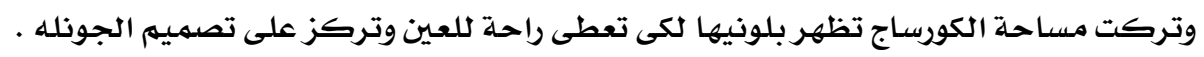

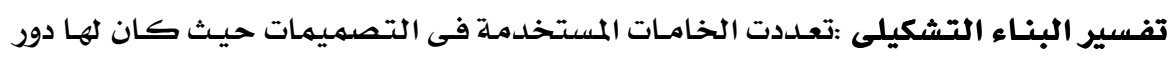

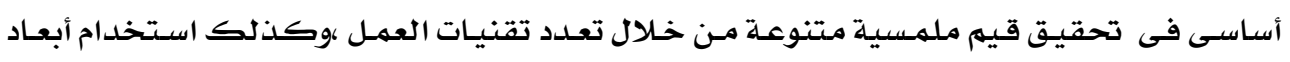

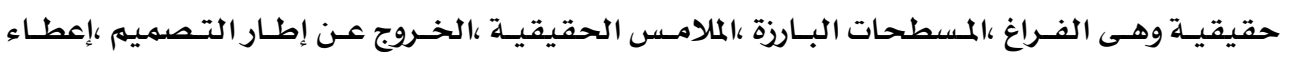

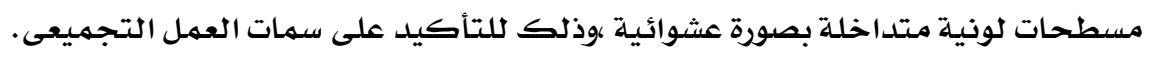

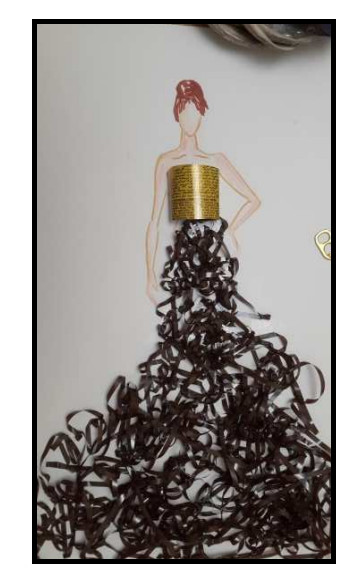

تصميه رقم (II) :

الخامات المستخلدمة :شرائط لينه من البلاستيك ،رقائق معدنية (صفيح)

تحليل التصميم :تصميم لفستان بكورساج على شكل اسطوانه تم تشكيلة برقائق معدنيـة

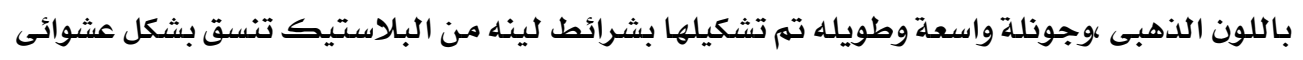

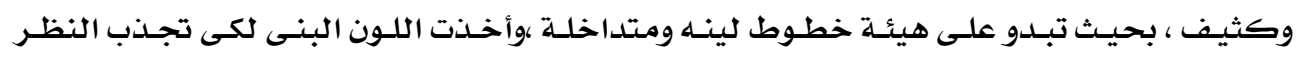
•للكورساج

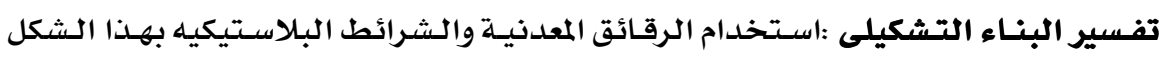

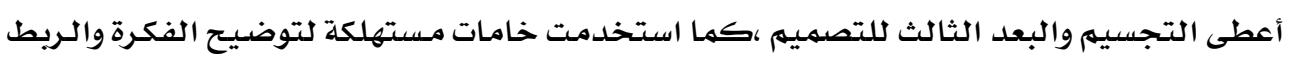

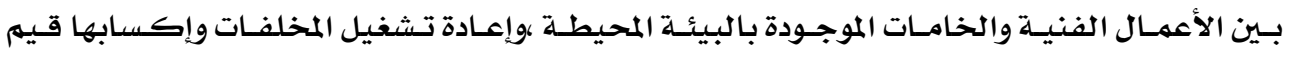
جمالية وفنية . 


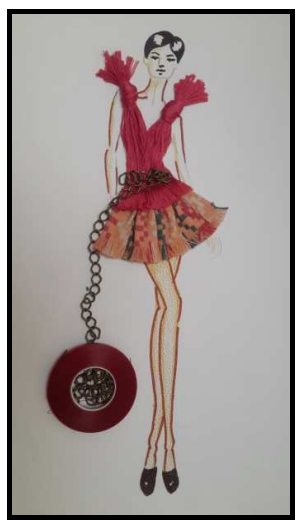

الخامات المستخدمة :قطع نسيج ،خيوط ،سلاسل ،اطار من البلاستيك.

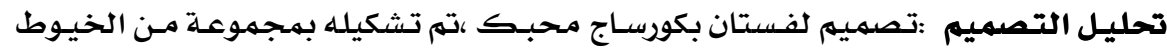

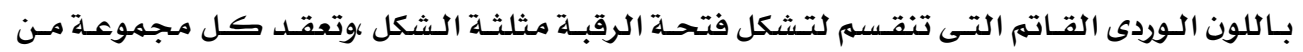

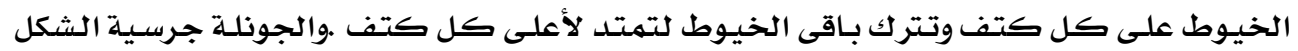

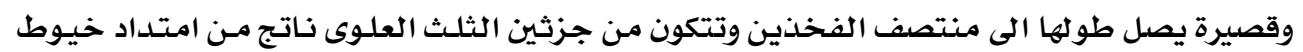

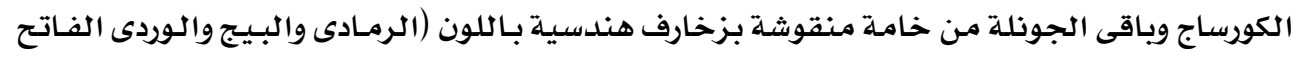

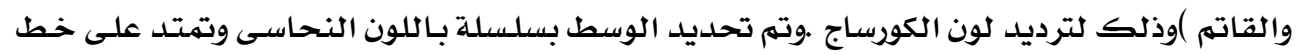

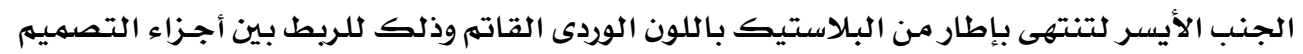

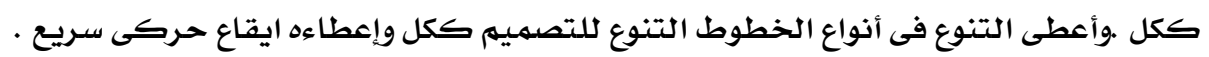

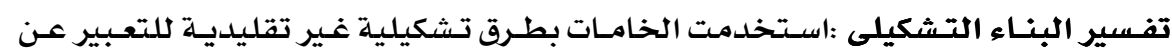

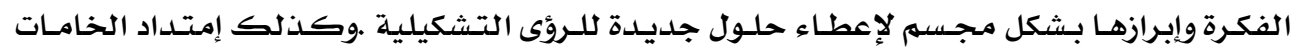

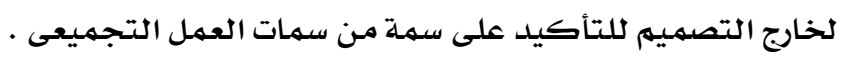

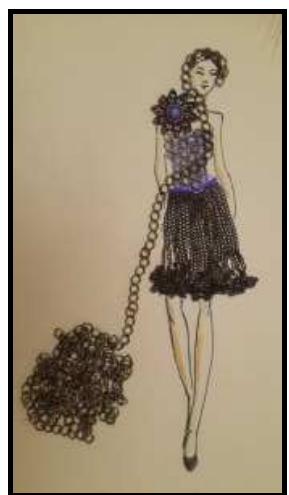

التصميه رقم (II) 
الخامات المستخدمة : سلاسل ،خرز ،حلقات معدنية ،قماش منسوج ،شريط زخرفى

تحليل التصميم :تصميم لفستان بكورساج محبك ، يصل طوله الى ما بعد الوسط بقليل

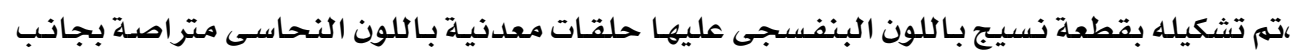

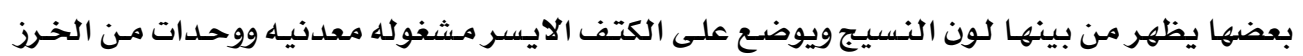

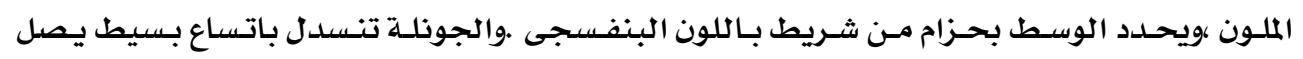

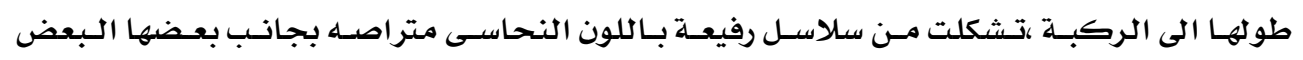

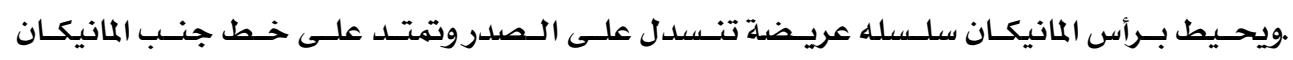
بشكل مكثف.

تفسير البنـاء التشكيلى : تعـددت الخامـات المستخدمـة فى التصميمات واستخدمت بطـرق

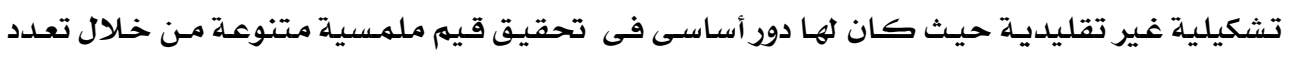

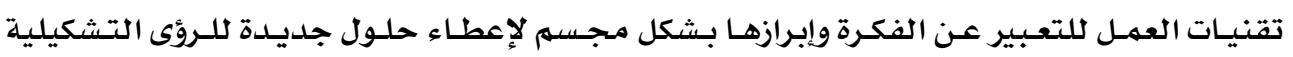

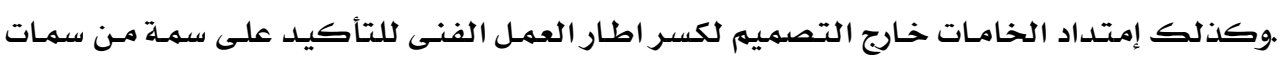

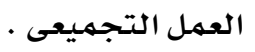

• التساؤل الخامس : ما هى آراء المتخصصين فى التصميمات التقترحة؟

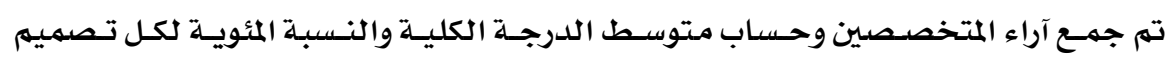
والجدول التالى يوضـح ذلك. جدول(1) متوسط الدرجة الكلية والنسب المئوية للتصميمات المقترحة وفقاً لآراء المتخصصين

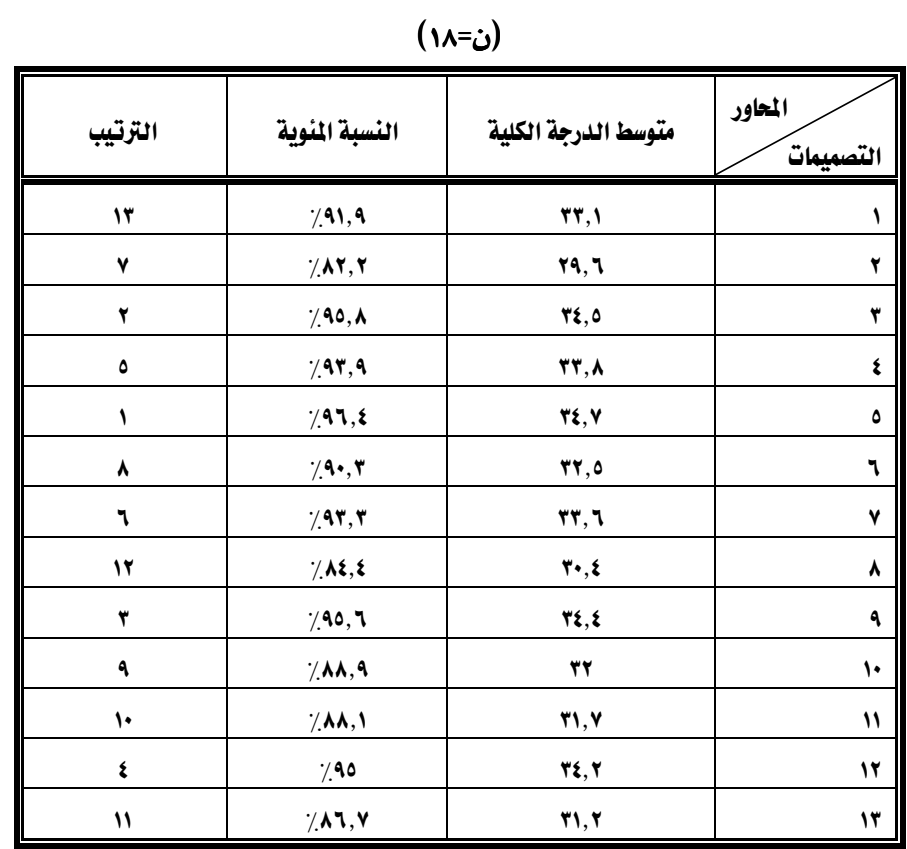




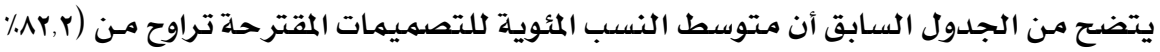

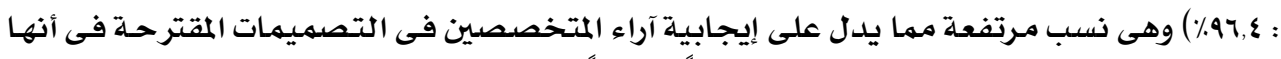

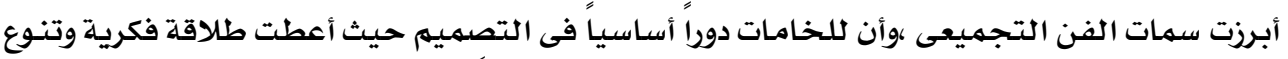

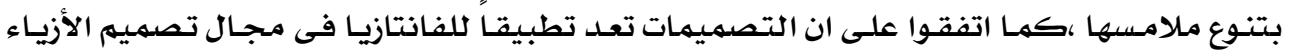

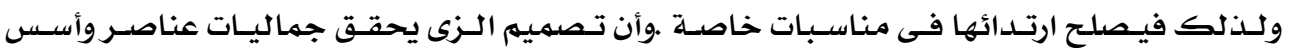

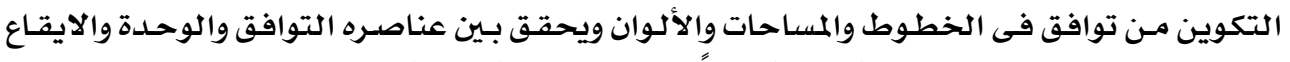

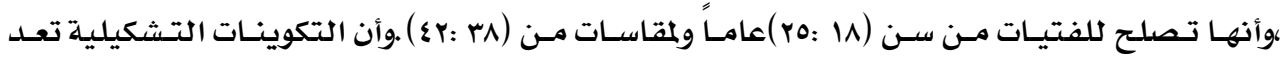

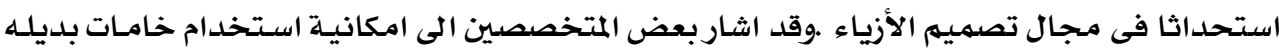

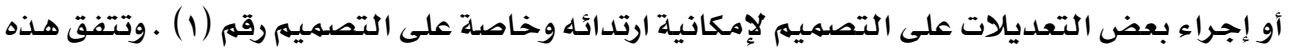

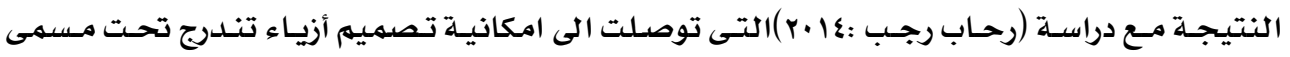

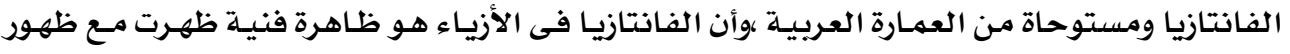

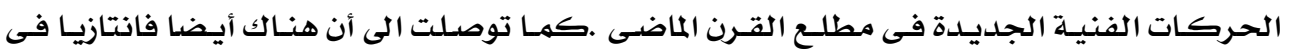

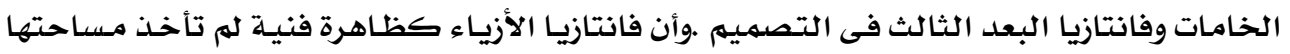

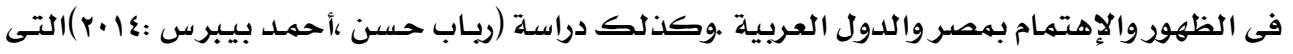

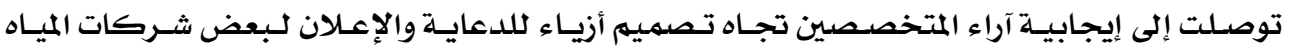

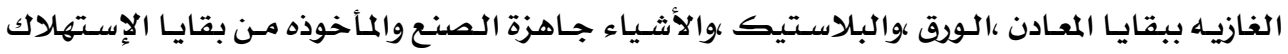

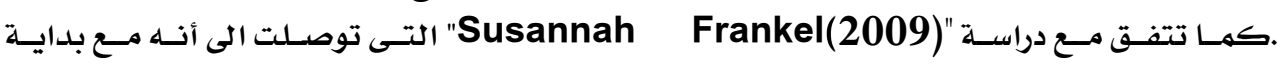

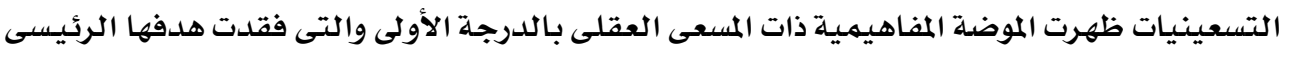

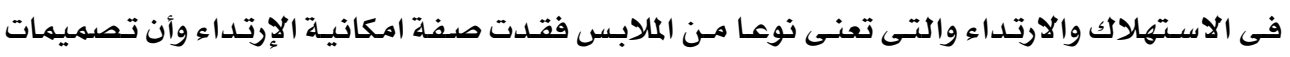

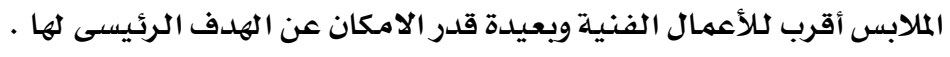

\section{نتائج الدراسة : نمربة}

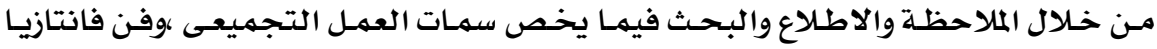

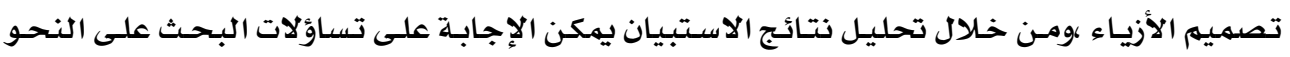
التالى:

ا. التوصل الى الأسس والمعايير التى يعتمد على أساسها بناء العمل التجميعى.

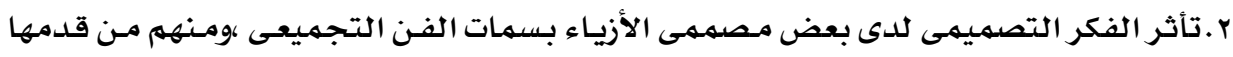

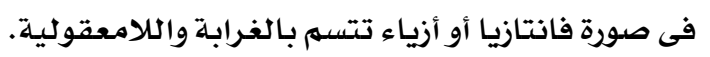

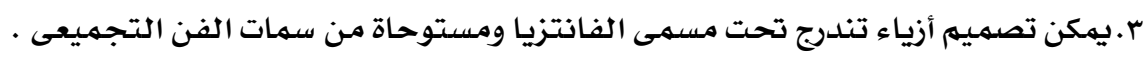

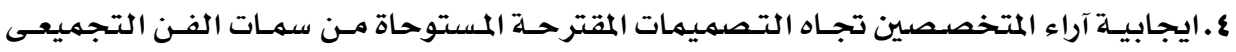

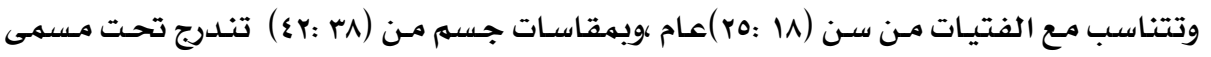

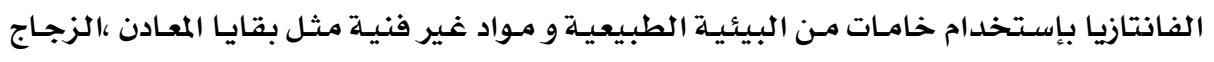

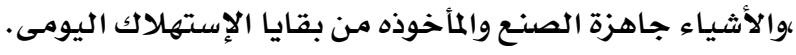


ا ـ تضمين موضوع تصميهم الأزياء بإسلوب الفن التجميعى داخل مقررات تصميم الأزياء بالكليات

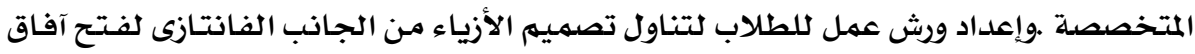

$$
\text { الابداع لديهم. }
$$

r . المزيد من الدراسات الخاصدة بتطبيقات تصميهم الموضدة والأزياء بالشكل غير التقليدى.

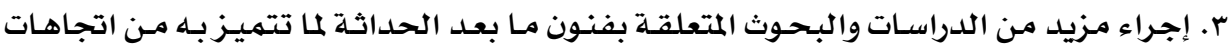

$$
\text { فلسفية وفنية حديثة تثرى مجال تصنية الصميم الأزياء. }
$$

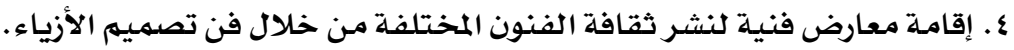

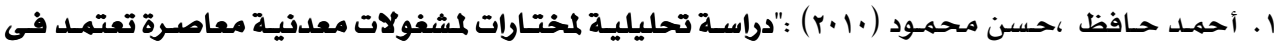

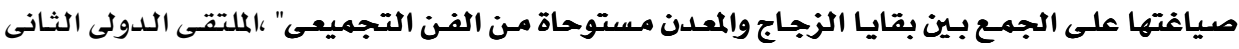

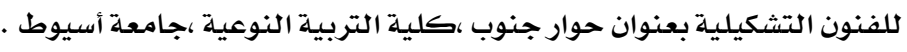

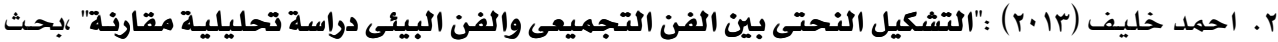

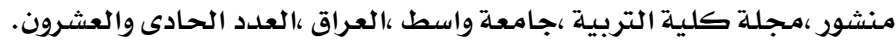

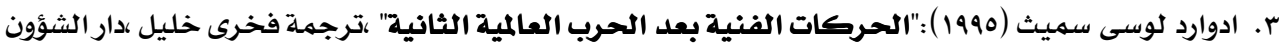
الثقافية العامة ،بغداد.

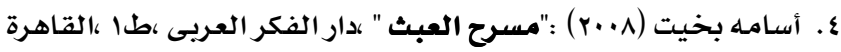

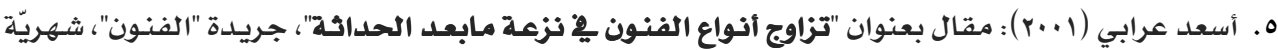

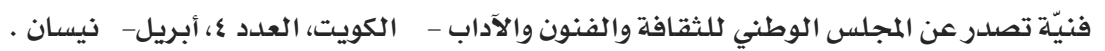

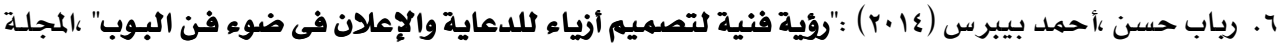
المصرية للإقتصاد المنزلى ،العدد الثلاثون.

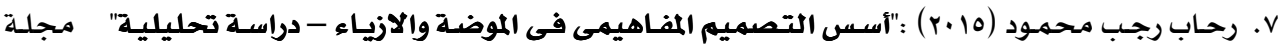

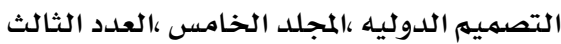

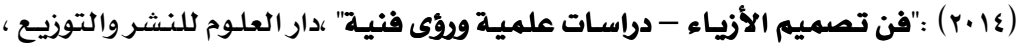
القاهرة

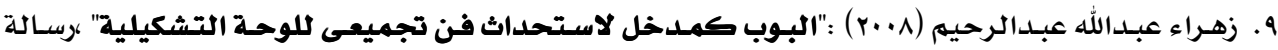

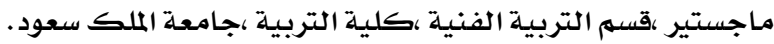
• ا.عادل ثروت عثمان (1999) :"العمل الفنى التجميعى كممدخل لإثراء التعبير فى التصوير" ،رسالة ماجستير غير منشورة ،كلية التربية الفنية ،جامعة حلوان.

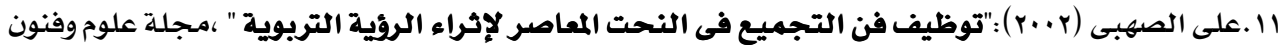

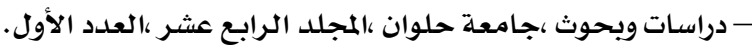

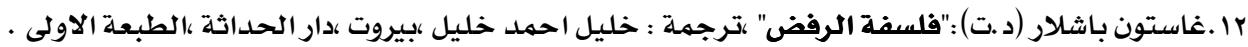




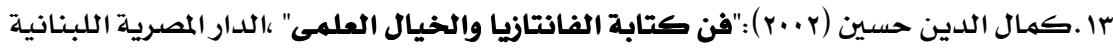

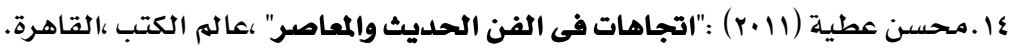

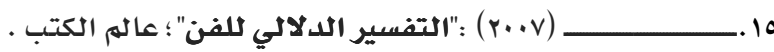

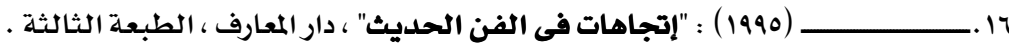

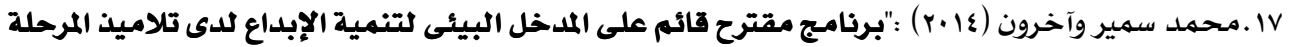
الابتدائية" ،بحث منشور ،مجلة العلوم التربوية ،العدد الثالث ،جر ،يوليو.

18. Judith (2010):" Sculpture today" phaidon New York,collinsk.

19. Oxford Dictionary (1999):"Oxford University press" ,first Published.

20. Socha, Miles (6 October 2014). "John Galliano Joins Maison Martin Margiela". New York: Women's Wear Daily. Retrieved 6 October 2014.

21. Susannah Frankel (2009):" The Birth, death and rebirth of conceptual fashion". New York. Rizzoli

22. Walker, John. (1992): "Assemblage Art". Glossary of Art, Architecture \& Design since 1945, 3rd. ed. Retrieved February 7, 2012.

23. William Benton (1996):" Encyclopedia Britannica" press company LTD.

24. https://www.pinterest.com/pin/147915168988375714

25. http://www.vogue.com/fashion-shows/spring-2015-couture/viktor-rolf

26. http://www.vogue.com/fashion-shows/fall-2016-couture/viktor-rolf

27. http://www.todayandtomorrow.net/2009/02/10/maison-martin-margielaartisanal-2

28. http://en.wikipedia.org/wiki/Hussein_Chalayan

29. http://www.selbyfleetwoodgallery.com/artists/christina_chalmers_-_paintings

30. http://artsyforager.com/2011/10/06/deconstructing-beauty

31. https://en.wikipedia.org/wiki/Alexander McQueen

32. http://www.nytimes.com/2011/05/03/fashion

33. ar.wikipedia.org

34. https://ar.wikipedia.org/wiki/2_شامبمارسيل

35. https://en.wikipedia.org/wiki/Assemblage (art)

36. https://en.wikipedia.org/wiki/Jean Dubuffet

37. http://www.wikiart.org/en/pablo-picasso/guitar-1912

38. https://www.moma.org/learn/moma_learning/marcel-duchamp-bic

39. https://www.moma.org/learn/moma_learning/robert-rauschenberg-bed-1955 


\section{Characteristics of The Assemblage Art as A Source of Fashion Fantasy Design}

\section{Abstract}

This research aims at; concluding the basics and standards of the assemblage work, analyzing models of international fashion designers whose works have been affected by the characteristics of the assemblage, presenting suggestions of fashion designs under the nomenclature of fantasy inspired from the assemblage art relevant for girls aged 18 to 25 years old with a size ranging from 38 to 42 and identifying the opinion of specialists regarding the proposed designs.

This research is important because it provides the fashion design field with raw materials enjoying formative capabilities and aesthetic criteria fit for artistic shaping. It is also important because it helps create novice experimental approaches to create designs based on the assemblage methodology that contributes in enhancing the idea of design. Moreover, it may benefit students studying fashion design at various educational institutions in their training on producing design suggestions that enrich the fashion design field and creating innovative artistic views.

The research was limited to studying the assemblage art and its artistic characteristics through analyzing models of formative arts of certain assemblage artists. In addition to presenting design suggestions for the fashion of girls aged 18 to 25 years old with sizes ranging from 38 to 42 under the nomenclature of fantasy using raw materials from the natural environment and non-artistic materials such as the remnants of metals, glass and ready-made items taken from the debris of human use that reflect the characteristics of the assemblage art.

\section{The research has concluded the following:}

1. reached the foundations and criteria based on which to build aggregate work.

2. The artistic design of certain fashion designers has been affected by the characteristics of the assemblage art; some of them presented it in the image of fantasy and others in freak and non-reasonable fashion.

3. Certain fashion can be designed under the nomenclature of fantasy inspired from the assemblage art.

4. The positive attitudes of both specialists and consumers towards the proposed designs. 


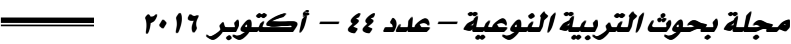

\section{ملحق رقم (1)}

استمارة آراء المتخصصين لتصميم فاتتازيا الأزياء المستلهمة من سمات فن التجميع

\begin{tabular}{|c|c|c|c|c|}
\hline 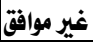 & |موافق إلى حلد ما & موافق & 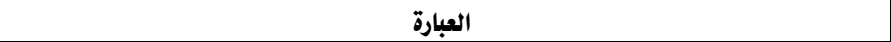 & 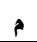 \\
\hline & & & يظهر التصميم السمات الفنية للعمل التجميعى. & 1 \\
\hline & & & التصميم يعد تطبيقاً للفاتزيا فى مجال تصميي الأزياء. & $r$ \\
\hline & & & تجميع الخامات المستخدمة اعطى طلاقة فكرية وتنوعا & $r$ \\
\hline & & & تلعب الخامات دوراً أساسياً فى التصميي. & $\varepsilon$ \\
\hline & & & يحقق التكوين التشكيلى استحداثاً فى مجال تصميي الأزياء. & 0 \\
\hline & & & تنوع السطوح الملمسية للخامات أعطت ثراء للتصميم & 9 \\
\hline & & & يحقق التصميه نوعاً من الوحدة بين عناصره الاساسية هى (الخط،اللون، الخامة) & $\checkmark$ \\
\hline & & & يحقق الزى جماليات الأسس البنائية للتكوين (التناسب - الوحدة - الإتزان - الإيقاع - التوافق .....) & $\wedge$ \\
\hline & & & يصلح التصميم لإرتدائه فى مناسبات خاصة (عروض فنية ، حفلات ،كرنفالات ......) & 9 \\
\hline & & & يصلح التصميم تنفيذه كملبس يمكن ارتداءه. & 1. \\
\hline & & & 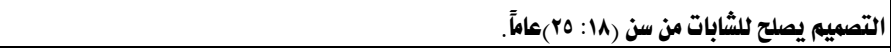 & 11 \\
\hline & & & |التصميم يصلح للقياسات من (r) r :). & ir \\
\hline
\end{tabular}




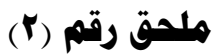

أسماء السادة محكمي الاستمارة والتصميمات لئ

\begin{tabular}{|c|c|c|}
\hline محكمي التصميمات & محكمي الاستمارة & الأسمـــاء \\
\hline & $\sqrt{ }$ & أ.د/ حاتم رفاعي أستاذ بقسم الملابس والنسيج - كلية الاقتصاد المنزلي - جامعة حلوان \\
\hline$\sqrt{ }$ & $\sqrt{ }$ & أ.د/ إيمان عبد السلام أستاذ بقسم الملابس والنسيج - كلية الاقتصاد المنزلي - جامعة حلوان \\
\hline$\sqrt{ }$ & $\sqrt{ }$ & أ.م.د / يسري معوض أستاذ مساعد بقسم الملابس والنسيج - كلية الاقتصاد المنزلي - جامعة حلوان \\
\hline$\sqrt{ }$ & $\sqrt{ }$ & أ.م.د/ كرامة ثابت أستاذ مساعد بقسم الملابس والنسيج - كلية الاقتصاد المنزلي - جامعة حلوان \\
\hline$\sqrt{ }$ & & أ.م.د / رحاب رجب أستاذ مساعد بقسم الملابس والنسيج - كلية الاقتصاد المنزلي - جامعة حلوان \\
\hline$\sqrt{ }$ & & أ.م.د/ أشرف عبد الحكيي أستاذ مساعد بقسم الملابس والنسيج - كلية الاقتصاد المنزلي - جامعة حلوان \\
\hline$\sqrt{ }$ & $\sqrt{ }$ & أ.م.د / حازم عبد الفتاح أستاذ مساعد بقسم الملابس والنسيج - كلية الاقتصاد المنزلي - جامعة حلوان \\
\hline$\sqrt{ }$ & $\sqrt{ }$ & أ.م.د / عبير إبراهيم أستاذ مساعد بقسم الملابس والنسيج - كلية الاقتصاد المنزلي - جامعة حلوان \\
\hline$\sqrt{ }$ & $\sqrt{ }$ & أ.م.د / سحر علي زغلول أستاذ مساعد بقسم الملابس والنسيج - كلية الاقتصاد المنزلي - جامعة حلوان \\
\hline$\sqrt{ }$ & $\sqrt{ }$ & أ.م.د / نجلاء عبد المجيد أستاذ مساعد بقسم الملابس والنسيج - كلية الاقتصاد المنزلي - جامعة حلوان \\
\hline$\sqrt{ }$ & $\sqrt{ }$ & أ.م.د / كرم مسعد أستاذ مساعد كلية التربية الفنية - جامعة حلوان. \\
\hline$\sqrt{ }$ & & د/حنان سعيد ملرس بقسم الملابس والنسيج - كلية الاقتصاد المنزلي - جامعة حلوان \\
\hline$\sqrt{ }$ & & د/هاله مصطفى مدرس بقسم الملابس والنسيج - كلية الاقتصاد المنزلي - جامعة حلوان \\
\hline$\sqrt{ }$ & & د/ أحمد بيبرس مدرس بقسم الملابس والنسيج - كلية الاقتصاد المنزلي - جامعة حلوان \\
\hline$\sqrt{ }$ & & د د دعاء عبود ملرس بقسم الملابس والنسيج - كلية الاقتصاد المنزلي - جامعة حلوان \\
\hline & & د/ رانيا سعد ملدرس بقسم الملابس والنسيج - كلية الاقتصاد المنزلي - جامعة حلوان \\
\hline$\sqrt{ }$ & & د/ هدى عبد المزيز مدرس بقسم الملابس والنسيج - كلية الاقتصاد المنزلي - جامعة حلوان \\
\hline$\sqrt{ }$ & & د/ هالة برهام مدرس بقسم الملابس والنسيج - كلية الاقتصاد المنزلي - جامعة حلوان \\
\hline$\sqrt{ }$ & & د/ ريهام يوسف مدرس بقسم الملابس كلية البنات - جامعة عين شمس \\
\hline
\end{tabular}

